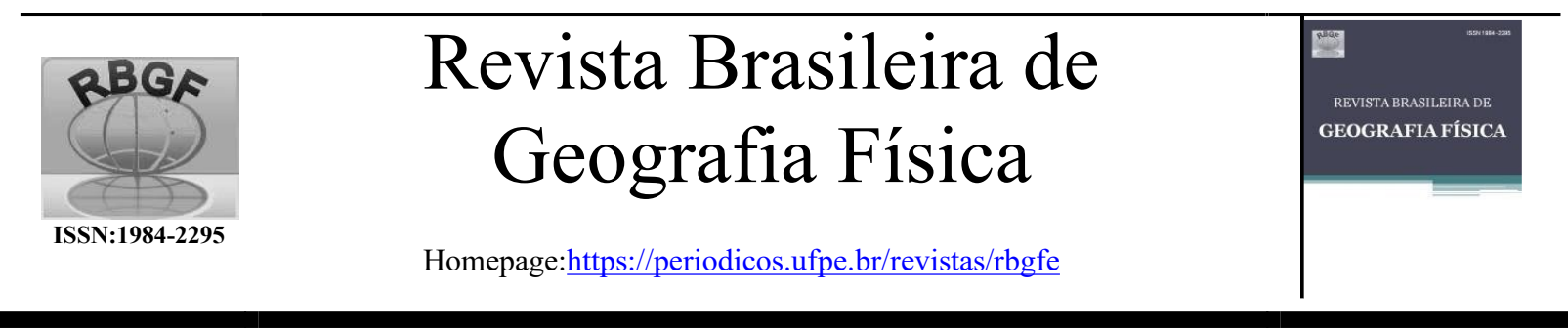

\title{
Carta da Paisagem das Américas: um olhar sobre sua construção e desafios
}

\author{
Lúcia Maria de Siqueira Cavalcanti Veras ${ }^{1}$
}

\begin{abstract}
${ }^{1}$ Dra. em Desenvolvimento Urbano, Professora Associada do Departamento de Arquitetura e Urbanismo da Universidade Federal de Pernambuco, Av. Acadêmico Hélio Ramos, s/n, Cidade Universitária, CEP 50.740-540, Recife, Pernambuco. (81) 2126-8771. luciamveras@yahoo.com.br; lucia.veras@ufpe.br.
\end{abstract}

Artigo recebido em 01/02/2021 e aceito em 04/03/2021

\begin{abstract}
R E S U M O
A Carta da Paisagem das Américas é fruto do compromisso dos países do continente americano, membros da Federação Internacional de Arquitetos Paisagistas da Região Américas (IFLA AR) com a elaboração de suas cartas nacionais e regionais de paisagem, com vistas à elaboração da Convenção Global da Paisagem. Publicada em 2018, a partir das 12 cartas já produzidas nas Américas e em sua maioria estimuladas pela Iniciativa Latino-americana da Paisagem (LALI), tem explicitamente como referência primeira a Convenção Europeia da Paisagem. Discutir seu conteúdo basilar e seu processo de construção até o produto final - fundamentado, essencialmente, no objeto empírico como ponto de partida definidor de seus princípios estruturadores, como a natureza, a cosmovisão, a cultura, a ética ambiental e a 'americanidade' como identidade - é o objetivo deste artigo. Estando em processo de implementação para ser homologada entre seus signatários, fecha-se esta discussão apontando-se os desafios implícitos formalmente em seus objetivos, reunidos em preocupações técnicas, políticas e voltadas à educação, bem como são apontados outros desafios em resposta às questões que já estão sendo levantadas nos fóruns de difusão e discussão necessários à sua apropriação e futura inserção em políticas de paisagem no continente americano.
\end{abstract}

Palavras-chave: paisagem, cartas de paisagem, América.

\section{Charter of the Landscape of the Americas: a look at its construction and challenges}

\begin{abstract}
A B S T R A C T
The Charter of the Landscape of the Americas is the result of the commitment of the countries of the North and South American continents, members of the International Federation of Landscape Architects of the Americas Region (IFLA AR), to drawing up their national and regional landscape charters, with a view to producing the Global Landscape Convention. This Charter, which was published in 2018 and which is based on the 12 charters already produced in the Americas and mostly stimulated by the Latin American Landscape Initiative (LALI), explicitly refers to the European Landscape Convention as the first point of reference. This article proposes to discuss the core content of the Charter and the process of its construction until the final product. This is based essentially on the empirical object as a starting point that defines its structuring principles, such as nature, cosmovision, culture, environmental ethics and 'Americanity' as identity. As the Charter is in the process of implementation prior to being ratified by its signatories, this discussion closes by pointing out the implicit challenges that are formally in its objectives, which have been brought together in technical and policy concerns that target education. Moreover, other challenges are pointed out in response to the questions that are already being raised in the forums that must be held to transmit and discuss these matters with a view to their being appropriated and inserted in the future into policies for the landscape of the continent of the Americas. Keywords: landscape, landscape charters, the Americas.
\end{abstract}

\section{Cartas introdutórias à Paisagem}

Associar Cartas à Paisagem está na origem da paisagem como conceito, atribuído ao relato do poeta italiano Francesco Petrarca sobre a escalada ao Monte Ventoux, na França do século
XIV, movido pelo simples desejo de apreender a paisagem que se descortinava do alto de uma montanha, com vistas alargadas para o horizonte distante. $\mathrm{O}$ relato de sua experiência paisagística, 
em forma de carta a um amigo, ${ }^{1}$ revela que Petrarca pôs em evidência "a postura moderna do olhar direto sobre o mundo, aquela da secularização da curiosidade, voltando, por assim dizer, à autópsia da natureza, um olhar até então dirigido aos livros" (Besse, 2006, p. 2). Ao inaugurar a passagem da Idade Média à Modernidade, o poeta explicita a capacidade de apreender a paisagem pelo olhar que do alto interroga e descreve o mundo e ainda que esteja distante, o esforço da subida o entrelaça à paisagem mais próxima, exigindo um exercício de autoconhecimento, como se percorrer o texto pensado e sentido também fosse escalar as palavras.

O olhar que traz para perto o distante abriu precedente para muitas outras aventuras, seguidas também por pintores de paisagens e assim, além das representações pictóricas da apreensão da natureza em forma de paisagem, a carta de Petrarca configura-se como um documento de leitura visual pela palavra escrita, definido como marco inaugural dirigido à paisagem.

Historicamente, a palavra de outras cartas também nos revela noções de paisagem e outras "inaugurações". Enquanto Petrarca sobe o Ventoux por puro prazer e relata as sensações que o panorama lhe desperta, dois séculos depois, no continente que viria a se chamar de América, mais precisamente nas terras do Brasil, Pero Vaz de Caminha escreve a Carta do Achamento do Brasil (Gumbrecht, 2003), enviada ao rei de Portugal em maio de 1500, expondo suas impressões sobre o lugar de chegada dos descobridores portugueses. Entre a transcrição da realidade capturada pela visão e a interpretação, essa é uma "carta relatória" (Mignolo, 1982 apud Giucci, 2003, p. 55) entendida como um documento histórico que

\footnotetext{
${ }^{1}$ Victor Gonçalves expõe que, sendo Petrarca poeta e eclesiástico, sua carta foi escrita para um 'confessor', o padre Dionísio do Burgo Santo Sepulcro, relatando a metáfora da ascensão, também, como "a superação do mundo empírico, suas coisas e sentimentos, em direção à transcendência" (Gonçalves, 2012, p. 106). Vladimir Bartalini refere-se a Dionísio como 'amigo e conselheiro espiritual' e para quem Petrarca também "relata as desorientações e o cansaço, as oscilações da vontade e as astúcias inúteis do corpo na busca de um caminho que conduzisse, sem agruras, ao alto". (Bartalini, 2007, s/p). Nesse sentido, Dionísio - amigo, conselheiro e confessor -, recebe uma carta reveladora de Petrarca que, ao expor as agruras que precisou superar, nos ajuda a contar o surgimento da paisagem como conceito pelo que é apreendido pelo olhar, só possível pelo esforço de sua subida, numa íntima relação entre corpo e paisagem.
}

Veras, L. M. S. C. tem o propósito de informar sobre as novas conquistas, ainda que não revele uma imersão apurada sobre os costumes nem a existência de diálogo entre os forasteiros e os povos nativos, o que precisaria, inclusive, de mais do que os dez dias transcorridos entre a chegada de Caminha e a escrita da carta e seu envio no dia $1^{\circ}$ de maio. No entanto, o gesto do escrivão revela um desejo pessoal de aproximação do desconhecido e um desejo de aproximar e partilhar o desconhecido novo mundo - que batizaram como Ilha de Vera Cruz - com a corte de Portugal.

E a Carta se desdobra. A partir da narrativa detalhada da Primeira Missa no Brasil, celebrada no dia 26 de abril de 1500 - quando se finca no solo uma cruz e se profere o Evangelho acompanhado por cerca de cinquenta habitantes locais além dos portugueses -, a descrição cuidadosa de Caminha inspira e estimula a criação de pinturas e gravuras dessa paisagem, justapondo sobre suas palavras, as imagens imaginadas da interpretação dos artistas. Como analisa Memory Holloway (2003, p. 64),

A Carta de Caminha, baseada em detalhes agudamente observados, registrados no seu diário, tem sido reconhecida como a narrativa que relata a descoberta do Brasil. Ao mesmo tempo, sua representação visual, através de pinturas e gravuras, constitui uma história paralela que ilustra e celebra a expansão e a conquista portuguesas. Ambos, texto e imagem, parecem aliviar o peso da narrativa que descreve viagens em forma de cartas e, desta forma, foge à padronização visual relativa às personagens exóticas.

Descoberta no século XIX, trezentos anos depois de escrita, a Carta de Caminha inspirou a pintura de Victor Meirelles, Primeira Missa (1860), que por sua vez inspirou a releitura de Meirelles por Paula Rego, A Primeira Missa no Brasil, em 1993 (Holloway, 2003). Ao se pintar a cena relatada, foi reconstruída a natureza como suporte - solo, vegetação, céu, montanhas e o horizonte ao longe, insinuando o litoral - e recomposta como cenário que tem a cruz como centro da composição, reverenciada pela multidão de nativos e portugueses que animam aquilo que se compreende não mais como natureza, mas como natureza recortada em forma de paisagem (Simmel, 2009). Como afirma Adriana Serrão (2012, p. 318), "a paisagem é uma peculiar forma do pensamento, irredutível tanto às categorias científicas quanto às qualificações aplicadas pela literatura às descrições sentimentais e pela pintura às tonalidades dos cenários reproduzidos ou imaginados". Ao atar texto e imagem, carta e 
pintura, o gesto inicial de Caminha permite a multiplicação de percepções que dão vitalidade à compreensão de paisagem e que, neste caso, é gesto inaugural do Brasil que se inventa paisagem. $^{2}$

As Cartas de Paisagem hoje guardam dessa origem mais pretérita o olhar abrangente sobre determinados territórios e, para além do registro da contemplação e das descobertas, estendem o propósito da descrição daquilo que é visto e entendido como paisagem para a sua compreensão como objeto e categoria do planejamento, da gestão e da conservação. Como documentos que guardam princípios éticos, devem auxiliar a construção de políticas públicas dirigidas à paisagem como bem coletivo. Segundo Jaume Busquets Fàbregas e Albert Cortina Ramos (2009, p. 430), Carta de Paisagem é

[... un instrumento voluntario de concertación y mediación entre los agentes públicos y privados del territorio dirigido a promover la mejora de los paisajes y la calidad de vida de las personas -mediante el establecimiento de objetivos de calidad paisajística, estrategias, medidas y acciones- a través de un programa de gestión dinámica del paisaje.

Assim, como instrumento-guia de princípios e diretrizes que congrega diferentes interessados unidos por um compromisso coletivo em favor da paisagem, deve representar o estabelecimento de diálogos e acordos mútuos, tanto públicos quanto privados, o que exigiria a participação em sua construção e/ou nos processos de discussão do texto, que antecedem a assinatura dos seus signatários. A nem sempre coincidência de opiniões deve assegurar a mediação pelo debate a ser incluído nesse trabalho.

Nesse sentido, propõe-se discutir o processo de construção e apontar desafios da Carta da Paisagem das Américas, apresentada

\footnotetext{
${ }^{2}$ Representações conceituais do mundo em linguagens como cartas, relatos, poesia, pinturas, gravuras expressam a força da retórica da paisagem como uma invenção. A construção mental como artifício desse processo é explorada por Anne Cauquelin em seu livro "A invenção da paisagem" (2007). No livro "La invención de América" (1984), Edmundo O’Gorman critica a atribuição da 'descoberta' do novo mundo, em 1492, aos espanhóis, quando na verdade, por terem chegado a terras há séculos descobertas por antigas civilizações, seus gestos estariam mais próximos de uma "invenção" eurocêntrica do que de uma “descoberta" eurocêntrica. No Brasil a "invenção" está na Carta do "achamento" de Caminha.

Veras, L. M. S. C.
}

oficialmente em setembro de 2018 na Cidade do México durante a Conferência Regional da Federação Internacional de Arquitetos Paisagistas Região Américas (IFLA AR), denominada "Descubrir los paisajes de las Américas: diseñar, planificar, conservar y gestionar". ${ }^{3}$ A Carta foi publicada em espanhol pela Revista Astragalos do México (Peñalosa et al., 2018), em português pela Associação Brasileira de Arquitetos Paisagistas (ABAP), em 2019, e pela IFLA, em três línguas, em 2020. ${ }^{4}$ O lançamento da Carta, construída por um Comitê Redator, ${ }^{5}$ foi uma das atividades de encerramento desse evento, que incluiu em sua programação palestras, painéis e premiação latinoamericana de projetos de Arquitetura da Paisagem. A condução dessa discussão foi aqui estruturada nos itens: (1) Convenção Europeia da Paisagem, instrumento propulsor, (2) "Da Paisagem das Américas" e não "Americana da Paisagem", (3) Princípios espelhados em Estratos: natureza, cosmovisão, cultura, ética e americanidade, e conclui dissecando desafios em (4) De Caminha aos caminhos futuros da paisagem das Américas: considerações finais.

\section{Convenção Europeia da Paisagem, instrumento propulsor}

Catástrofes, exploração e destruição de paisagens, fruto inclusive de incorretas decisões políticas, podem ser entendidas como algumas das provocações para se pensar em instrumentos que ajudem a assegurar o futuro das paisagens. A Convenção Europeia da Paisagem (CEP) é reconhecida como o documento propulsor para se pensar a paisagem por instrumentos legais, de direito jurídico, que, ao considerar a paisagem como patrimônio intrínseco, extrapola o âmbito da Europa e é referência internacional para outros continentes.

3 Esta conferência, promovida pela IFLA AR e Universidad Autónoma Metropolitana, unidad Azcapotzalco (UAM-A), contou com a parceria da Sociedad de Arquitectos Paisajistas de México (SAPM), da Facultad de Arquitectura da Universidad Nacional Autónoma de México (UNAM) e do Seminario de Cultura Mexicana (SCM).

${ }^{4}$ Em novembro de 2020, a IFLA divulga oficialmente a Carta nas versões em espanhol, português e inglês.

5 O Comitê Redator foi composto por arquitetos envolvidos com a paisagem em diferentes campos de atuação: Raquel Peñalosa (Presidente da IFLA AR, Canadá), Saúl Alcántara (UAM-A/SCM/México), Carlos Jankilevich (IFLA AR, Costa Rica), Lúcia Veras (Laboratório da Paisagem da Universidade Federal de Pernambuco - UFPE, Brasil) e Maria Teresa Ocejo (UAM-A, México). 
A Convenção Europeia da Paisagem, disponibilizada para assinaturas pelo Conselho da Europa em 20 de outubro de 2000, na cidade de Florença, foi, na verdade, precedida de outros instrumentos preparatórios, quatro deles apontados por Dora Lampreia (2012, p. 258-259) ao discutir a importância da adoção desse instrumento para a definição de políticas de paisagem: (1) Recomendação Paris Paisagens e Sítios, referente à "salvaguarda da beleza e do caráter das paisagens e dos sítios" (1962), (2) a Convenção de Benelux referente à Conservação da Natureza e Proteção da Paisagem, ratificada pela Bélgica, Países Baixos e Luxemburgo (1982), (3) a Carta da Paisagem Mediterrânica ou Carta de Sevilha (1993), exposta na Terceira Conferência das Regiões do Mediterrâneo e que estabelece políticas de gestão e conservação e a importância dos estudos para o reconhecimento dos valores da paisagem e (4) a Recomendação n. R(95)9, que discorre "Sobre a conservação integrada das áreas de paisagem cultural como parte das Políticas de Paisagem" (1995), de onde se recorta o entendimento do conceito de paisagem adotado pela Convenção. Para Lampreia (2012, p. 260) a CEP é

[...] um documento conceptual e orientador, que define um corpo teórico e instrumental que servirá de base às estratégias a adoptar por cada Estado membro, deixando em aberto a forma como estes o irão incluir nos seus sistemas legislativos e administrativos.

Ao considerar que todas as paisagens são relevantes - "a paisagem é em toda a parte um elemento importante da qualidade de vida das populações" (Convenção Europeia da Paisagem, 2000, p. 1) -, a convenção as divide em três categorias: as paisagens excepcionais, as cotidianas e as degradadas. As excepcionais são aquelas que, em sua maioria, já possuem proteção legal por serem dotadas de grande valor estético e/ou patrimonial. As cotidianas, são aquelas da vida comum, onde as pessoas estabelecem suas relações, e por isso mesmo, dotadas de grande valor social. As degradadas são aquelas abandonadas que carecem de uma maior atenção e que por isso devem ser inseridas no sistema para sua requalificação (Veras, 2014). A preocupação com o conjunto, aponta um olhar sistêmico.

Proteger, gerir e ordenar são as palavraschave que vão estruturar este documento e orientar outros que dele irão se desdobrar extrapolando a Europa, principalmente a partir dos compromissos que começam a surgir em congressos internacionais promovidos pela IFLA. Em 2006 inicia-se o interesse por uma visão mais Veras, L. M. S. C. global, consolidada em 2010, em Suzhou na China, durante o $47^{\circ}$ Congresso Internacional de Arquitetura da Paisagem promovido pela Federação Internacional de Arquitetos Paisagistas (IFLA), quando os 64 países membros se comprometeram com a elaboração de suas cartas nacionais de paisagem visando à construção da Convenção Global da Paisagem. Esta estaria respaldada pela Organização das Nações Unidas para a Educação, Ciência e Cultura (UNESCO) e pela Organização das Nações Unidas (ONU), agora numa dimensão global, com o objetivo de promover a proteção, a gestão e o ordenamento das paisagens, entendidas como bem e direito de todos por contribuir para a melhoria da qualidade de vida e do bem estar social.

O congresso de Suzhou incentivou a elaboração de cartas nacionais de paisagem, algumas reorganizadas no nível regional ou continental, com o objetivo de cobrir os cinco continentes componentes das cinco Regiões da IFLA. Nas Américas, o pioneirismo se deu com a Colômbia, país que gerou um movimento denominado Iniciativa Latinoamericana del Paisaje (LALI) e que suscitou o propósito de se construir uma carta latino-americana de paisagem, além de provocar a elaboração de outras cartas de países da América Latina se somando ao pioneirismo da própria Colômbia. Em 2018, a IFLA Américas e instituições parceiras propõem ampliar o olhar para além da América Latina, agora sobre as Américas e constroem a Carta da Paisagem das Américas (CPA).

A Convenção Europeia da Paisagem, que inspirou e inspira outras cartas fora da Europa, foi discutida por seis anos - de 1994 a 2000 (Zoido Naranjo, 2009) -, e seu caráter inovador se inicia pela própria compreensão de paisagem que traz para o conceito a condição de sua apreensão pelo senso comum, e que aquilo que é apreendido por essa população resulta da interação entre fatores naturais e humanos. Este cunho inovador se estende à caracterização das paisagens - das notáveis às não tão notáveis assim - e às atitudes a elas associadas que incorporam em seu planejamento a proteção, o gerenciamento e o ordenamento, suporte para a gestão do território. Estes gestos - conceituar, caracterizar e definir atitudes de ação -, lhes conferem conceitualmente um caráter internacional, indo além da exclusividade para um continente, o que define sua dimensão global.

Assim, embora seja uma ferramenta voltada para as paisagens europeias, é a referência internacional que tem desencadeado muitos outros instrumentos legais voltados à paisagem. Como propulsor, instiga instrumentos que proliferam a 
partir dela, propagando-se para além da exclusividade europeia na criação de cartas nacionais de paisagem. Num movimento contrário, a Carta da Paisagem das Américas foi construída a partir de outras cartas das Américas e, portanto, caracteriza-se como ponto de convergência dessas cartas, por sua vez também inspirados na CEP, costurando-as agora com um olhar continental. Esta distinção de construção e desenvolvimento está ilustrada na Figura 1.
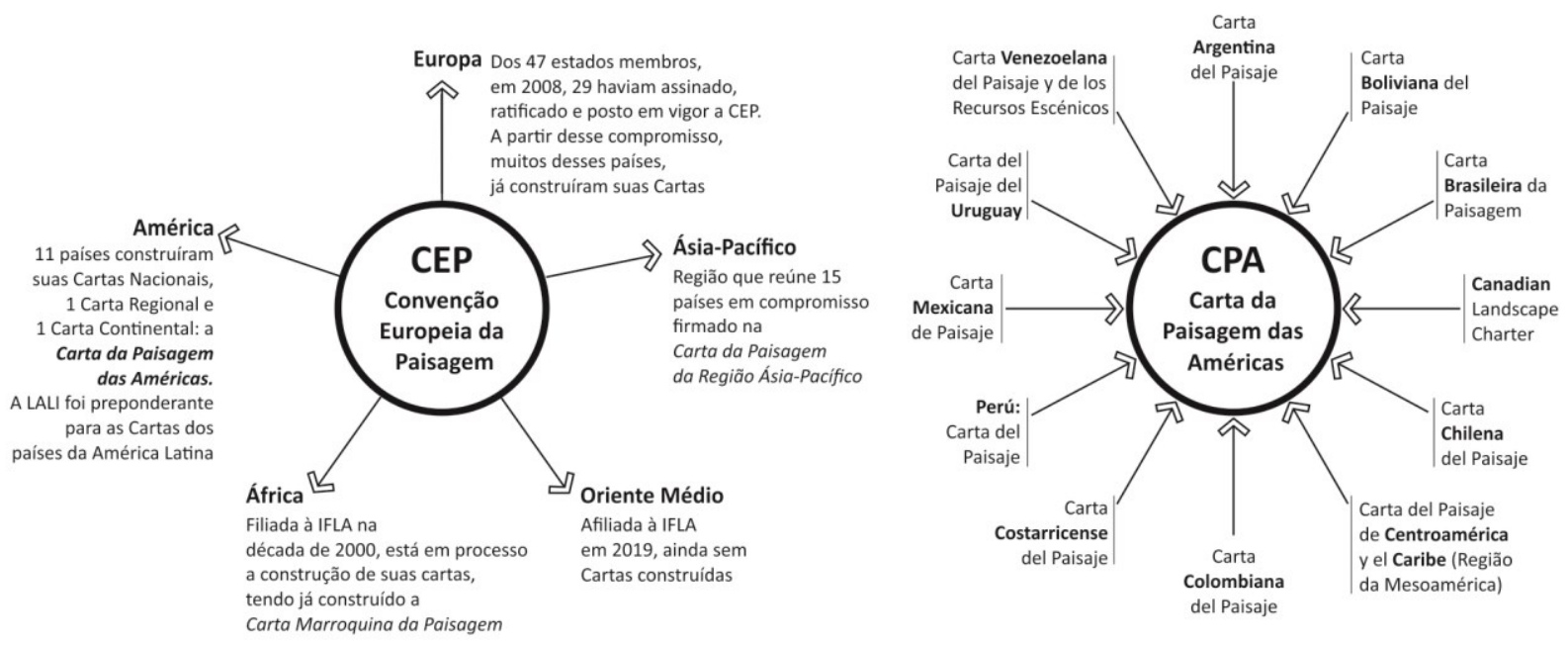

Figura 1 - Relação entre a concepção da CEP e da CPA. Da CEP proliferam cartas para os cinco continentes. Para a construção da CPA, doze Cartas da Paisagem americana alimentaram seu processo, além das referências da própria CEP.

As cinco regiões que se expandem a partir da CEP são aquelas definidas pela IFLA, representante oficial do conjunto dos arquitetos paisagistas em todo o mundo, que hoje congrega 77 associações distribuídas nas regiões da África, América, Ásia-Pacífico, Europa e Oriente Médio. Os Arquitetos Paisagistas associados às suas instituições nacionais e estas à IFLA têm sido os principais responsáveis pela construção das Cartas de Paisagem em todo o mundo. Nesse processo, a IFLA também se articula com organizações governamentais e não governamentais como a UNESCO, ONU e União Internacional dos Arquitetos (UIA).

A Figura 1 ilustra que em 2008, dos 47 membros do continente europeu, 29 já tinham assinado, ratificado e posto em vigor a CEP. Entre estes, vários já elaboraram suas cartas nacionais de paisagem ou estão em fase de construção, ressaltando o trabalho exemplar da Espanha com a elaboração dos Catálogos de Paisagem voltados para o planejamento territorial (Nogué Font e Sala Martí, 2009). Estes fazem parte de um rigoroso método de trabalho que envolve o diagnóstico e a definição de diretrizes de ação culminando com o estabelecimento dos acordos, tendo nesse processo a participação de especialistas, de instituições públicas e da população (Busquet Fàbregas e Cortina Ramos, 2009).
A Figura 1 também ilustra que convergem para a CPA as 12 Cartas de Paisagem produzidas nas Américas, das quais uma corresponde à região da América Central e do Caribe. ${ }^{6}$ Até 2018, dos 17 países filiados à IFLA Região Américas, cinco ainda não haviam construído suas cartas nacionais de paisagem, sendo eles as Bermudas, o Equador, os Estados Unidos, o Paraguai e Porto Rico. ${ }^{7}$ O processo de construção da Carta da Paisagem das Américas contou com a convergência da maioria dos membros filiados do continente, partindo-se do pressuposto de que estas cartas nacionais também se inspiraram na Convenção Europeia da Paisagem, com apreensão de paisagem próxima àquela definida nesse instrumento, bem como a adoção dos seus fundamentos, agora voltados às Américas. A Tabela 1 discrimina o país, a instituição representante dos arquitetos paisagistas de cada país e o título das cartas de paisagem por eles construídas e que alimentaram a Carta da Paisagem das Américas.

\footnotetext{
${ }^{6}$ A América Central e o Caribe reúnem os países da região também denominada de Mesoamérica, que inclui o sul do México.

7 Entre estes países, em maio de 2020, durante o II Congreso Internacional del Paisaje de Quito, é apresentada a Carta del Paisaje del Ecuador.
} 
Tabela 1 - Países afiliados à IFLA Américas, Instituições de Arquitetos Paisagistas por países e as Cartas de Paisagem produzidas até 2018.

\begin{tabular}{lll} 
País & Instituição & Carta produzida \\
\hline $\begin{array}{l}\text { Argentina } \\
\text { Bolívia }\end{array}$ & $\begin{array}{l}\text { Centro Argentino de Arquitectos Paisajistas } \\
\text { Sociedad Arquitectos Paisajistas, Ecología y Medio } \\
\text { Ambiente }\end{array}$ & Carta Argentina del Paisaje \\
Carta Boliviana del Paisaje \\
\hline Canadá & Associação Brasileira de Arquitetos Paisagistas & Carta Brasileira da Paisagem \\
\hline Chile & Canadian Society of Landscape Architects & Canadian Landscape Charter \\
Colômbia & Instituto Chileno Arquitectos Paisajistas & Carta Chilena del Paisaje \\
\hline Costa Rica & Sociedad Colombiana de Arquitectos Paisajistas & Carta Colombiana del Paisaje \\
México & Asociación Costarricense de Arquitectos Paisajistas & Carta Costarricense del Paisaje \\
\hline Peru & Sociedad de Arquitectos Paisajistas de México & Carta Mexicana de Paisaje \\
Uruguai & Asociación Peruana de Arquitectura del Paisaje & Perú: Carta del Paisaje \\
\hline Venezuela & Asociación Uruguaya de Arquitectura de Paisaje & Carta del Paisaje del Uruguay \\
América Central & Sociedad Venezolana de Arquitectos Paisajistas & Carta Venezolana del Paisaje y de \\
e Caribe & Asociación de Paisajismo de Centroamérica y & los Recursos Escénicos \\
\hline
\end{tabular}

Dos conceitos inovadores introduzidos pela Convenção Europeia da Paisagem importa assinalar que, além do próprio conceito de paisagem, que incorpora o fator social como determinante sobre aquilo que se apreende por paisagem, a Carta da Paisagem das Américas também parte das três palavras-chave da Convenção - proteção, gestão e ordenamento -, ajustando-se, no entanto, às especificidades desse novo documento que se volta às Américas.

Nesta transposição, há uma substituição da palavra "proteção" por "conservação" e da palavra "ordenamento" por "planejamento e desenho", mantendo-se a palavra "gestão". Em sua origem, proteção e conservação estão associadas aos movimentos ecológicos em favor da natureza, surgidos com força na década de 1960, principalmente a partir do interesse pela conservação do meio ambiente exposto pelos Estados Unidos na elaboração de estudos de Avaliação de Impactos Ambientais (AIA). Em essência, a AIA é "un trabajo previo a la aprobación de cualquier planeamiento, programa o proyecto de obra que afecte al suelo. Tal trabajo se realiza con el objetivo de prevenir los posibles daños que pueda provocar en el medio ambiente incluido el Patrimonio Cultural-y su equilibrio" (Querol, 2010, p. 97).

Do ponto de vista ambiental, tanto a "proteção" quanto a "conservação" distanciam-se da intocabilidade inerente à "preservação" da natureza, que a vincula a um pensamento preservacionista próprio da preocupação com a manutenção de áreas de natureza excepcional, consideradas patrimônio ecológico de grande valor. A União Internacional para a Conservação da Natureza (UICN) define "conservação" como "a gestão do uso humano da biosfera para que ela possa produzir o maior benefício sustentável para as gerações atuais enquanto mantém seu potencial para atender às necessidades e aspirações das gerações futuras" (UICN, UNEP e WWF, 1980 apud Borrini-Feyerabend et al. 2017, p. 13). Ao se compreender a paisagem como fruto sociocultural daquilo que é percebido pelas populações, coube a decisão pela conservação e o desafio de construir um instrumento voltado, tanto para a proteção de paisagens como para a gestão de suas transformações, o que exige, necessariamente, planejamento e desenho.

A substituição da palavra "ordenamento" por "planejamento e desenho" deixa mais explícita a mesma preocupação com o futuro, pelo gesto de "desenhar", próprio do arquiteto da paisagem, a partir de decisões dialogadas com outros profissionais e das leituras do território realizadas a partir de outros campos do conhecimento. $\mathrm{O}$ ato de desenhar, vinculado ao ato de projetar, evidencia a importância de se "recuperar a capacidade de projetar modificações que saibam ser também esteticamente válidas, ou seja, que não desfigurem a identidade dos lugares, ainda que transformando-a onde for necessário" (D’Angelo, 2011, p. 438). É provável que, de forma intuitiva, a substituição de "proteção" por "conservação" e a inclusão das palavras "planejamento e desenho" tenham tido influência da experiência de alguns dos especialistas redatores da $\mathrm{CPA}$, professores com atuação tanto em desenho de paisagem em disciplinas de Projeto no Curso de Arquitetura e Urbanismo da Universidade Federal de Pernambuco do Brasil, como da Pós-graduação em Diseño, Planificación y Conservación de Paisajes y Jardines da 
Universidad Autónoma Metropolitana unidad Azcapotzalco do México, Pós-graduação em paisagem e jardim, que já incorpora essas palavras em sua estrutura de ensino e pesquisa. A "gestão" como conceito se mantém e em ambos os instrumentos é clara a associação entre a importância da sustentabilidade e da participação social para uma efetiva gestão.

Essa transposição está na Tabela 2, que traz os conceitos das palavras-chave dos dois instrumentos correlacionados: a Convenção Europeia da Paisagem (2000) e a Carta da Paisagem das Américas (2018).

Tabela 2 - Conceitos-chave da Convenção Europeia da Paisagem e da Carta da Paisagem das Américas.

\begin{tabular}{|c|c|}
\hline $\begin{array}{r}\text { CEP } \\
\text { (2000) Convenção Europeia da Paisagem }\end{array}$ & $\begin{array}{l}\text { CPA } \\
\text { Carta da Paisagem das Américas (2018) }\end{array}$ \\
\hline $\begin{array}{r}\text { Proteção } \\
\text { Designa as ações de conservação ou manutenção } \\
\text { dos traços significativos ou característicos de } \\
\text { uma paisagem, justificadas pelo seu valor } \\
\text { patrimonial resultante da sua configuração } \\
\text { natural e ou da intervenção humana }\end{array}$ & $\begin{array}{l}\text { Conservação } \\
\text { Consiste em definir um conjunto de ações e } \\
\text { estratégias com o propósito de manter e transmitir } \\
\text { para o futuro, tanto quanto possível, os traços e } \\
\text { significados característicos de uma paisagem, que } \\
\text { por seu valor patrimonial pode ser entendida como } \\
\text { um documento-paisagem, considerando a natureza e } \\
\text { a ação do homem sobre o território. }\end{array}$ \\
\hline $\begin{array}{r}\text { Gestão } \\
\text { Designa a ação visando assegurar a } \\
\text { manutenção de uma paisagem, numa } \\
\text { perspectiva de desenvolvimento sustentável, } \\
\text { no sentido de orientar e harmonizar as } \\
\text { alterações resultantes dos processos sociais, } \\
\text { econômicos e ambientais. }\end{array}$ & $\begin{array}{l}\text { Gestão } \\
\text { É o conjunto de ações, estratégias e métodos } \\
\text { definidos com o propósito de garantir a conservação } \\
\text { de uma paisagem, bem como orientar suas } \\
\text { transformações, levando em conta as dinâmicas } \\
\text { resultantes dos processos sociais, econômicos e } \\
\text { ambientais, numa perspectiva de desenvolvimento } \\
\text { sustentável, que deve incluir a efetiva participação } \\
\text { social. }\end{array}$ \\
\hline \multirow[t]{2}{*}{$\begin{array}{r}\text { Ordenamento } \\
\text { Designa as ações com forte caráter } \\
\text { prospectivo visando a valorização, a } \\
\text { recuperação ou a criação de paisagens. }\end{array}$} & $\begin{array}{l}\text { Planejamento } \\
\text { Consiste em estabelecer linhas de desenvolvimento } \\
\text { sustentável de uma paisagem em relação às } \\
\text { demandas e necessidades das sociedades, } \\
\text { entendendo essa paisagem como um bem primário. } \\
\text { Deverão ser consideradas a salvaguarda, a } \\
\text { preservação, a defesa, a requalificação da paisagem } \\
\text { e a recuperação ou reabilitação de áreas degradadas, } \\
\text { em diferentes escalas, incluindo paisagens únicas ou } \\
\text { características que desempenharão um papel } \\
\text { essencial na busca e criação de novos valores } \\
\text { paisagísticos e estéticos. Os fundamentos teóricos } \\
\text { desta escala de ação são baseados em estudos } \\
\text { ecológicos com contribuições de várias disciplinas. }\end{array}$ \\
\hline & $\begin{array}{l}\text { Desenho } \\
\text { É a arte de prever, de forma prospectiva, a } \\
\text { arquitetura de espaços livres para usos específicos, } \\
\text { com ordem e qualidade, levando em consideração } \\
\text { os condicionantes ambientais e o contexto cultural } \\
\text { de cada tecido urbano e/ou ambiente natural, com a } \\
\text { finalidade de melhorar, restaurar e/ou criar novas } \\
\text { paisagens, bem como privilegiar o manejo da } \\
\text { vegetação nativa e endêmica de cada território. }\end{array}$ \\
\hline
\end{tabular}

Fontes: Convenção Europeia da Paisagem (2000) e Carta da Paisagem das Américas (2018). 
Conservar, gerir, planejar e desenhar são as palavras-chave que vão estruturar a Carta da Paisagem das Américas, que, tomando a Convenção Europeia da Paisagem como referência e sobre a qual foram estruturadas as cartas nacionais das Américas que lhe alimentaram, ajusta o seu foco para as idiossincrasias que identificam as Américas e que guiaram a sua construção.

\section{"Da Paisagem das Américas" e não "Americana da Paisagem"}

No discurso de posse como presidente da IFLA Américas, gestão iniciada em 2014, a arquiteta paisagista Raquel Peñalosa assinala suas preocupações, compromissos e o desejo de construir uma carta de paisagem para o continente americano, avançando os estudos da Iniciativa Latino-americana da Paisagem (LALI), a partir da valorização de nossa "americanidade". Sendo colombiana de origem e na ocasião morando no Canadá, referiu-se à necessidade de criação de "pontes" para transpor limites e interligar o território que define a diversidade das Américas. Afirma Peñalosa ${ }^{8}$ que

Miguel de Unamuno inventó la palabra "americanidad" desde la lengua para hablar de las peculiaridades de nuestro continente. ¿Cuáles serían estas peculiaridades de nuestro continente que nos permitan afirmar, hoy la identidad globalizada de un paisaje americano? Que nos permitan definir de manera holística, los valores de paisaje al cual podamos afirmar una pertenencia y reconocer su riqueza cultural, geográfica, humana tanto ancestral, como actual. [...] En esta visión, les propongo que reescribamos juntos esta narrativa de la "americanidad" desde el paisaje. Que nos permita establecer una agenda americana de la Arquitectura del Paisaje de nuestra Región IFLA Américas, que pueda influenciar a más alto nivel los grandes cambios necesarios para una mejor sociedad y paisaje a nivel local y global. Trabajando en sinergia con la LALI hacia la definición de una Carta Americana del Paisaje.

O discurso de Peñalosa expõe o desejo de se trabalhar na construção de uma carta "americana" da paisagem, instigando a exploração

\footnotetext{
${ }^{8}$ Trecho da mensagem de boas-vindas do discurso de posse proferido por Raquel Peñalosa, presidenta da IFLA Região das Américas, em 15 de agosto de 2014.

Veras, L. M. S. C.
}

do próprio conceito de americanidade, reportandose a Miguel de Unamuno, "reconhecido como um dos primeiros autores a se interessar em conhecer 'as coisas da América"' (Santos, 2016, p. 2). Nas palavras de Unamuno (2002, p. 31), "Al hablar, pues, de americanidade [...] quiero hablar de aquellas cualidades espirituales, de aquella fisionomía moral -mental, ética, estética y religiosa- que hace al americano americano [...]". Unamuno cria a palavra americanidade assim como argentinidad e se refere ao uso de españolidad e de hispanidad (Unamuno, 2002, p. 31). Suas referências à americanidade se apoiam na linguagem, aproximando os países de língua espanhola numa "americanidade hispânica". Para Unamuno, "si hay algo de común entre esos pueblos -intelectualmente quiero decir -, es lo que les da la lengua común, con lo que de ella deriva. Un nicaragüense [...] piensa en castellano, créalo o no y quiera o no quiera" (2002, p. 174). Adotar a americanidade pela língua, ainda que sejam irmãs as neolatinas castelhana e português, afastaria o Brasil desse sentido e deste contexto.

Segundo Zilá Bernd, o conceito de "americanidade" é dotado de grande ambiguidade e carrega "um anseio de afirmação identitária, mas abrangente, para além das nacionalidades, dos gêneros e das etnias, por tratar-se de um desafio de identidade continental" (2008, p. 1). O desafio se expressa na heterogeneidade que contrapõe desníveis sociais e econômicos extremos, mesclados em diferentes culturas construídas em diferentes tempos históricos e o maior dos incômodos se dá pela apropriação inadequada do termo - "ser americano" - pelos estadunidenses. Esclarece Bernd (2008, p. 3) que

\begin{abstract}
A ambiguidade vem do fato desses cidadãos não se nomearem estadunidenses, mas americanos, num processo metonímico hipervalorizante. Enquanto os habitantes dos países latino-americanos estavam se empenhando em definir-se como argentinos, uruguaios, colombianos, brasileiros, etc, [sic] implicados em resolver a questão da identidade nacional, os estadunidenses se apropriaram dos termos América e "americano", fazendo com que hoje, quando se fala de "cultura americana" ou "cinema americano" ou simplesmente quando dizemos que "fulano é americano", por exemplo, associa-se o adjetivo, em primeiro lugar, aos Estados Unidos.
\end{abstract}

Essa usurpação "americana" dos estadunidenses, que mantém o impasse arraigado em pleno século XXI, justifica o descarte da 
denominação de Carta Americana da Paisagem, adotando-se a denominação de Carta da Paisagem das Américas. Nesse sentido, considerando as três Américas como um só continente, assume-se a denominação de "Paisagem das Américas" e não "Paisagens da América". Assim, a "americanidade" que se pleiteia para o norte, centro e o sul do continente é dada pela Paisagem (no singular) como conceito que une as Américas (no plural) Anglo-saxônica e Latina como um só continente. E assim, no Prefácio (Carta del Paisaje de las Américas, 2018, p. 3), afirma-se que:

A Carta da Paisagem das Américas baseia-se na busca de nossas raízes e da razão de nossa existência, baseadas no conhecimento de quem somos e do que possuímos como

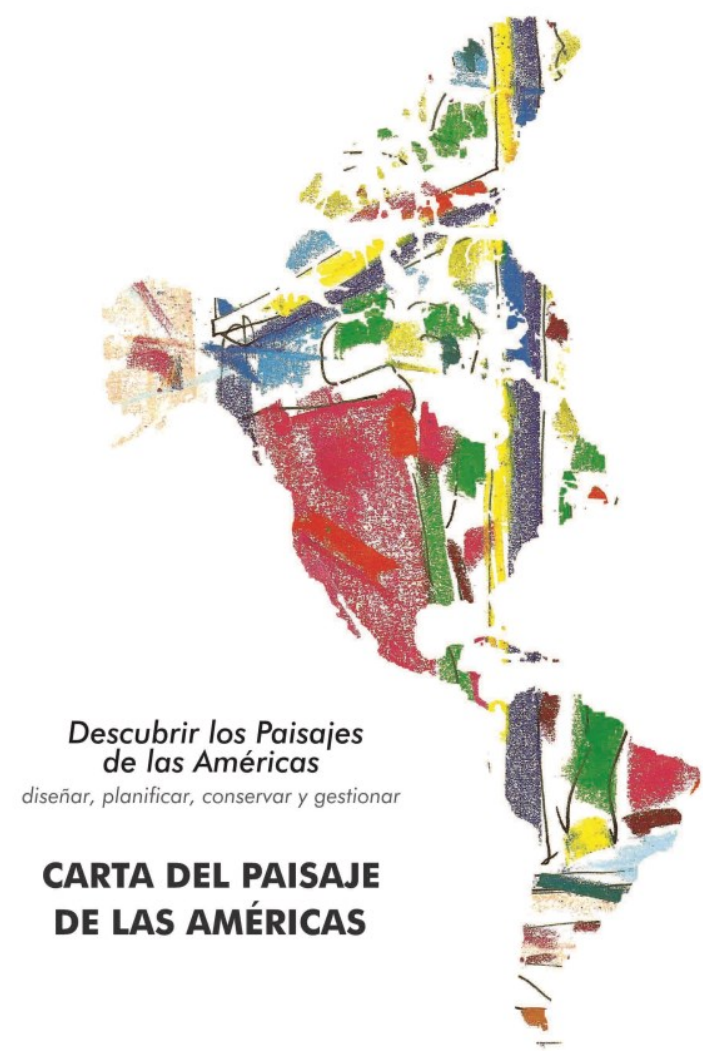

americanos, habitantes das Américas. Tal demanda é uma das razões fundamentais que vêm motivando a elaboração das cartas nacionais da paisagem e é uma característica distintiva e marco conceitual para o continente americano. Propõe-se assim que o filtro de entendimento de nossas paisagens como identidade, seja a partir da compreensão de nossa "americanidade", aquela do diálogo permanente entre a diversidade do território e da cultura.

$\mathrm{Na}$ criação da identidade visual da Conferência Regional da IFLA Américas em 2018, no México, foi utilizado um mapa do continente americano, com limites entre países esgarçados pela pintura Oporto (1994), do arquiteto mexicano Luis Barragán (Figura 2).

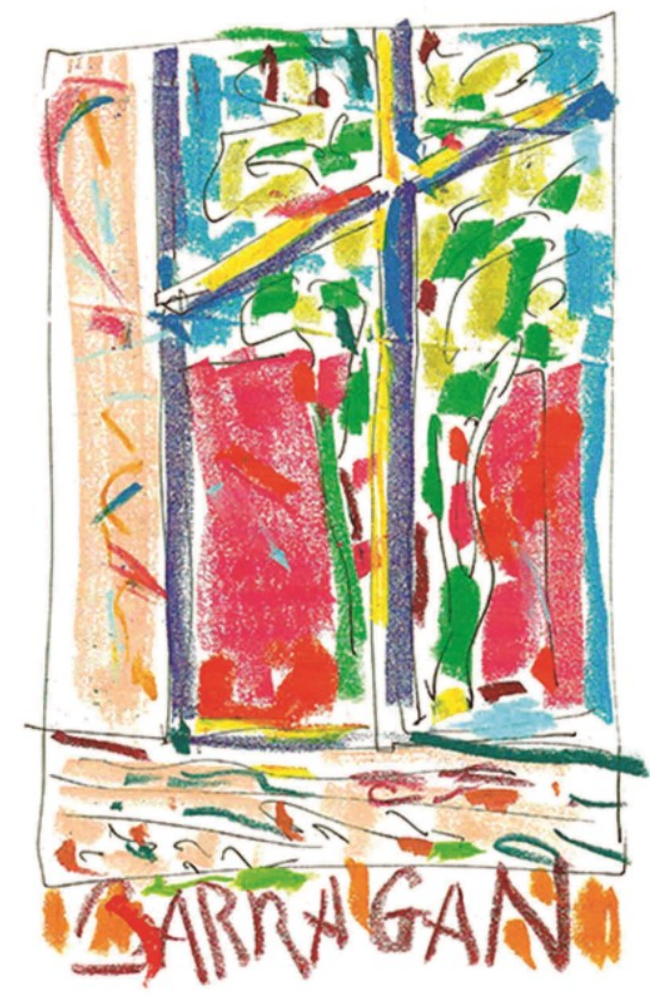

Figura 2 - Identidade visual da Conferência Regional da IFLA AR e da Carta da Paisagem das Américas, com mapa do continente reconstruído a partir da pintura Oporto (1994), de Luis Barragán. Fonte: https://njth10.wixsite.com/iflaamericas2018uama. Acesso em: 3 fev. 2020.

Como metáfora da americanidade, tingese a América de norte a sul e sem a definição de fronteiras entre países, reconstrói-se um sentido de unicidade pela diversidade das cores e texturas da pintura do artista.
Esta pintura de Barragán ${ }^{9}$ poderia ser entendida como metáfora, também, de sua própria arquitetura. Sendo um dos mais importantes

9 Miguel Hirata e Jorge Salmerón foram os responsáveis pela criação da identidade gráfica do evento Regional da IFLA Américas em 2018, que teve Luis Barragán como fonte de inspiração. 
arquitetos do século $\mathrm{XX}$, trouxe para a arquitetura a paisagem, mesclando o infinito do jardim à finitude dos espaços da arquitetura, tingindo-os de cultura local mexicana. Sendo do México, localizado no centro geográfico das Américas (Figura 3), Barragán ${ }^{10}$ foi escolhido para representar os expoentes do continente que ao norte, resguarda o pioneirismo de Frederick Law Olmsted, criador da denominação profissional da "Arquitetura da Paisagem" (Schenk, 2008) e ao sul, o inusitado e pioneiro paisagismo moderno de Roberto Burle Marx, que, ao priorizar as plantas tropicais brasileiras em projetos de paisagem, é reconhecido como um dos mais importantes paisagistas do Século XX. Como artista plástico, também, Burle Marx funde arte e paisagem e como paisagista, concebendo jardins como "reintegração estética dos elementos da natureza", cria o "jardim moderno brasileiro" (Silva et al., 2019, p. 1).

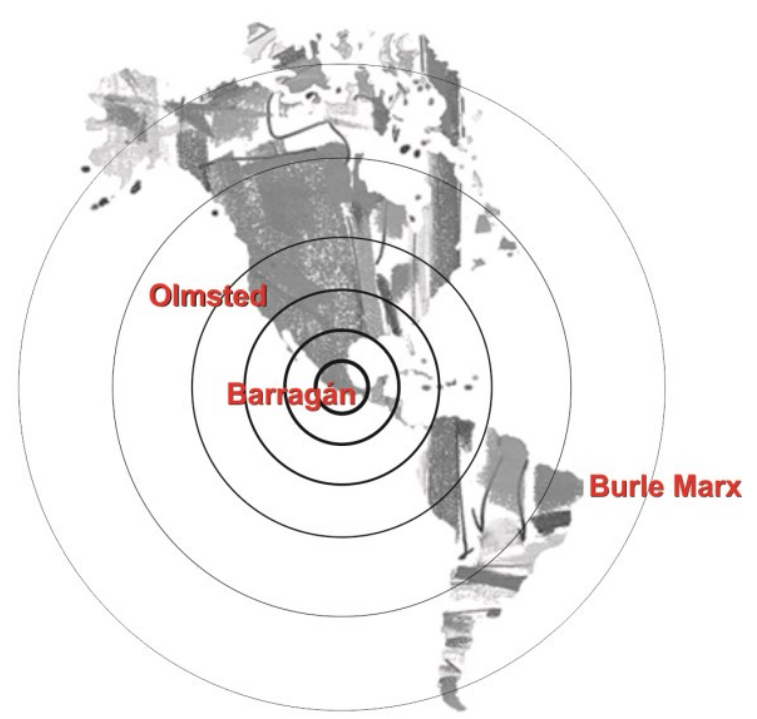

Figura 3 - Influentes (experts) paisagistas das Américas no Norte e do Sul - Frederick Law Olmsted e Roberto Burle Marx - representados pelo arquiteto, também arquiteto paisagista, Luis Barragán, do México, geograficamente posicionado no epicentro das Américas.

Ser uma carta "da paisagem das Américas" e não uma carta "americana da paisagem", por certo exigiu nesse esforço de

$10 \mathrm{O}$ arquiteto mexicano Luis Barragán também foi pintor, porém foi como arquiteto que se tornou mundialmente reconhecido e sua produção lhe valeu o Prêmio Pritzker, recebido em 1980, tornando-o único mexicano a ganhá-lo até os dias de hoje.

Veras, L. M. S. C. compreensão do continente, uma incursão na diversidade de suas paisagens. Essa desembocou na "(re)descoberta da paisagem americana" e definição dos Princípios espelhados em seus Estratos, a partir das leituras sobre a natureza, a cosmovisão, a cultura, a ética associada à estética e a americanidade como identidade.

\section{Princípios espelhados em Estratos: natureza, cosmovisão, cultura, ética e americanidade}

Do ponto de vista formal, a Carta da Paisagem das Américas é composta pelo Prefácio, Preâmbulo (América em 5 Estratos), 7 Considerandos, 5 Princípios, 18 Objetivos, 6 Definições/Glossário e a Declaratória. Essa estrutura obedece às exigências formais de um instrumento conceitual orientador que auxilie os Estados membro a definir estratégias jurídicas e administrativas voltadas ao planejamento, a gestão e a conservação de suas distintas paisagens, sendo um guia facilitador de acordos que devem ser estabelecidos entre os seus signatários em favor da paisagem das Américas.

O Prefácio a situa entre outros instrumentos e compromissos a partir de Suzhou, na China em 2010, respaldada pela Organização das Nações Unidas para a Educação, Ciência e Cultura (UNESCO), instituição especializada da Organização das Nações Unidas (ONU), deixando claro, de partida, que tem como objetivo maior o "direito à paisagem como um bem coletivo" e define como propósito

[...] promover a conscientização sobre a recuperação e valorização da paisagem, bem como elaborar instrumentos que favoreçam o desenvolvimento de um arcabouço legal, baseado na realidade presente, considerando o passado para se construir o futuro (Carta del Paisaje de las Américas, 2018, p. 3).

A estrutura segue o protocolo para os outros itens, desde os Considerandos que situam as Américas como parte de um sistema e preocupações globais, à construção dos Princípios, espelhados nos Estratos explorados no Preâmbulo. Numa visão mais ampla, os Considerandos expõem a preocupação não só das Américas como continente, mas como parte de um sistema global expondo questões que afetam o planeta.

Assim, partindo-se da compreensão da importância de se pensar o futuro respaldado no passado e no presente e o reconhecimento de que o direito à paisagem deve ser assegurado para as presentes e futuras gerações, os Considerandos 
(Carta del Paisaje de las Américas, 2018, p. 6-7) apontam (1) "a necessidade de se estabelecer um olhar especial para a paisagem das Américas" que compreenda e respeite a unidade que se faz de sua diversidade físico-geográfica, histórica, religiosa e sociocultural e que esse olhar se manifeste no planejamento, gestão, conservação e desenho de novas paisagens; (2) "a necessidade de reposicionar a mirada para uma noção de paisagem" incorporando seu caráter híbrido de natureza e cultura no gesto dos que decidem o futuro das paisagens em contínuo processo de educação patrimonial; (3) a necessária revisão dos "paradigmas que mantêm a insustentabilidade [reconhecidos como] danosos à conservação da biodiversidade," ponderando-se a relação entre natureza, necessidades sociais e produção econômica; (4) que todos somos responsáveis pela "mudança climática e o aquecimento global", cabendo às grandes cidades um papel definidor por serem grandes produtoras de elementos patogênicos que destroem a camada de ozônio e, por isso mesmo, (5) reconhecê-las "como paisagens [...] que exigem tratamentos especiais" e que esse reconhecimento considere (6) "a fragilidade das paisagens como elementos da cultura e patrimônio não-renovável" que testemunham exemplares notáveis da arquitetura assim como formas de vida comunitária e apropriação cultural. Por fim, os Considerando reconhecem (7) "o papel e a responsabilidade do Arquiteto da Paisagem na preservação, conservação e produção de novas paisagens", pontuando a importância do gesto de se afastar do conceito de "tábula rasa" ou de "museificação" dos lugares, para se projetar a partir do diálogo com os lugares que impõe o respeito às suas preexistências.

Estas preocupações lastrearam o processo de construção de um exercício que exigiu uma meticulosa leitura das 12 cartas produzidas nas Américas, aplicando-se a análise de conteúdo como "técnica de investigação que através de uma descrição objetiva, sistemática e quantitativa do conteúdo manifesto das comunicações tem por finalidade a interpretação destas mesmas comunicações" (Berelson, 1971 apud Bardin, 1977, p. 38). Essa leitura possibilitou se extrair especificidades, preocupações e valores que as próprias cartas produzidas já apontavam. Era preciso "(re)descobrir a América" pelo olhar das Américas e situá-la entre outras preocupações globais que a ela se articulam, explícitas nos Considerandos que antecedem a definição dos Princípios.

Da análise de conteúdo das cartas e preocupações com questões globais, cinco palavras-chave saltaram com força de síntese, inter-relacionando os Princípios espelhados no que se chamou de Estratos das Américas: (1) natureza, (2) cosmovisão, (3) cultura, (4) ética e (5) "americanidade" como identidade.

A decomposição em estratos, como "capas" que se superpõem, foi tomada como metáfora de desconstrução e reconstrução pautada no propósito de melhor se compreender a paisagem das Américas e as paisagens da América para se construir um instrumento específico para nossa realidade. Se os estratos desconstroem, os princípios reconstroem e espelhados, Princípios e Estratos serão analisados a seguir.

\section{Princípio primeiro: compreender-se como parte de um todo vivo}

O primeiro Princípio, espelhado no primeiro Estrato, pauta-se na natureza como condição e suporte de existência, e é definido por:

\begin{abstract}
Compreender-se como parte de um todo vivo, como condição primeira que antecede a todos os outros Princípios, por nos situar na base vital e fisiológica de nossa existência por sermos parte constituintes da natureza, de cuja consciência e respeito ao todo vivo depende a conservação e não a extinção da vida no planeta. A compreensão do todo vivo é um dever de todos e o todo vivo como paisagem, é um direito de todos (Carta del Paisaje de las Américas, 2018, p. 7).
\end{abstract}

Compreender-se como parte de um todo vivo implica situar-se entre os seres vivos do planeta, entendendo-se a própria natureza como legado biológico e base vital de nossa existência. Que suporte físico-geográfico possibilitou a construção desse continente e permitiu que distintas formas de ocupação do território revelassem sua natureza continental?

Sendo em área o segundo maior continente do planeta, a América reúne trinta e cinco países e dezoito dependências, distribuídos entre dois polos terrestres - do Alasca à Patagônia - e entre os oceanos Glacial Ártico, Glacial Antártico, Atlântico e Pacífico. Estender-se de norte a sul ora em grandes massas territoriais, como o Canadá, Estados Unidos e o Brasil, ora em fragmentadas ilhas de distintas configurações, como as ilhas do Caribe, ou mesmo em faixas delgadas de territórios que permitem a junção entre o Pacífico e o Atlântico no Panamá, ou ainda que se afunilam quase se desfazendo ao tocar as águas do sul do Chile e Argentina, faz deste um continente plural, que também se revela na heterogeneidade climática resultante da 
confluência entre a variação de latitudes, de altitudes e influências costeiras - terras altas de montanhas, terras baixas na linha do mar. Como pisos ecológicos distintos, saímos da fria Cordilheira dos Andes no Pacífico - do Chile, Argentina, Bolívia, Peru, Equador e Colômbia às quentes praias tropicais brasileiras de mais de sete mil quilômetros de extensão, ou das Montanhas Rochosas dos Estados Unidos e Canadá no Pacífico aos Montes Apalaches a leste, que resguardam modernas cidades banhadas pelo Atlântico. Da justaposição desses fatores, distintas camadas de vegetação cobrem ou descobrem o solo, em dunas, tundras, savanas, desertos e florestas tropicais, subtropicais e temperadas, como a Floresta Amazônica, maior bosque húmido tropical do planeta, que recobre nove países latino-americanos, concentrando-se no Brasil e recobrindo, por exemplo, mais da metade das terras do Peru. A teia desse sítio natural com flora e fauna específicas ajuda a entender, do ponto de vista histórico, a identidade que vai se construindo do extraordinário trabalho de adaptação e superação das limitações impostas pela natureza aos povos americanos, como se tivéssemos que nos compreender como parte desse suporte, como um todo vivo.

\section{Princípio segundo: recuperar a cosmovisão e a visão de sacralidade}

O segundo Princípio, espelhado no segundo Estrato, pauta-se na cosmovisão e visão de sacralidade e é definido por:

\begin{abstract}
Recuperar a cosmovisão e a visão de sacralidade, como uma das características intrínsecas que definem a formação do americano, fruto da relação que os povos originários estabeleceram com a terra e com seus deuses, dando sentido à sua existência. A Cosmovisão é uma forma de ver a vida que continua a ser expressa na contemporaneidade da paisagem americana, reverberando-se nas tradições, costumes e arte, onde a consciência sensível não se apoia em conceitos, mas em experiências, na herança construída da relação ancestralmente estabelecida entre os primeiros americanos e as terras da América (Carta del Paisaje de las Américas, 2018, p. 7).
\end{abstract}

Reconhecer a superposição que culturalmente vai se construindo sobre essa natureza exuberante constitui o que se denomina de segundo Estrato da paisagem americana, aquele que diz respeito às questões que se constroem da experiência vivida no espaço e no tempo e flutuam entre a presença física das coisas e a espiritualidade. A cosmovisão expressa o sagrado, os sentimentos da alma e da estética apurada pela arte, o misticismo do épico, mas também do trágico, do simples e do sublime próprios do imaginário individual e coletivo dos povos originários aos contemporâneos. A natureza distinta do primeiro Estrato exigiu inúmeras formas de adaptação às variedades climáticas e apropriação do continente, a partir dos coletores, caçadores e agricultores, definindo vínculos sagrados com a "mãe terra", que produziram diferentes culturas e paisagens de norte ao sul das Américas. Para os primeiros povos, os valores espirituais transcendentais expressavam a crença numa relação cósmica que "acreditavam regular os astros e a natureza", com consequências diretas na produção de alimentos para sua subsistência.

Essa relação ancestral se manifesta também no gesto de construção de cidades, como revelam as ruínas de cidades originárias do México - Teotihuacán, Palenque, Chichén Itzá -, da Guatemala como Tikal, do Peru, como Machu Picchu, ou ainda em centros espirituais, culturais e políticos, como o monumento de Tiwanaku, em Tiauanaco na Bolívia. A cosmovisão como herança atravessa as Américas e é mantida até os dias de hoje na resistência dos povos indígenas, do Canadá, Estados Unidos, México, Guatemala, Equador, Peru, Bolívia, Colômbia, Paraguai, Venezuela e do Brasil, neste último, cerca de 250 etnias falam mais de 150 línguas e dialetos (Krenak, 2019). Com rebatimento na paisagem, este sentido se revela na arquitetura originária e preservada das primeiras cidades da Mesoamérica ${ }^{11}$ e dos Andes - dos maias, incas, astecas e olmecas, entre outros povos -, e se estendeu aos pequenos povoados, originados da rica mescla entre os povos primitivos e os seus colonizadores. Nas Américas colonizadas pelos espanhóis, as cidades originárias - conhecidas como pré-hispânicas ${ }^{12}$ - e os pequenos povoados

11 As cidades do esplendor mesoamericano centralizaram não só o culto à religião, mas os sacerdotes detinham conhecimento sobre o calendário, a escrita, a iconografia e a astronomia, e a arquitetura e a urbanística eram vinculadas à ordem celeste (López Austin e Milliones, 2012, p. 27).

12 Há controvérsia a essa denominação. Ser "préhispânico" é colocar a chegada dos espanhóis como marco zero da existência deste continente e pontuar toda a sua história a partir da data do descobrimento aferida a 1492. Não seriam os espanhóis "pósoriginários" ao invés dos originários "pré-hispânicos"? (inquietações que fazem parte da pesquisa "América, uma civilização "paisageira": identificação de 
hispânicos carregam testemunhos dessa mistura cultural que expressa parte do sincretismo da paisagem americana como narrações míticas de uma forma de pensar e construir o território, no contraponto da relação cósmica entre a posição do homem no universo e o universo que carrega dentro de si (Wolf, 1967).

\section{Princípio terceiro: considerar as singularidades do palimpsesto do território}

O terceiro Princípio, espelhado no terceiro Estrato, volta-se em especial para as cidades, produto da cultura expressa em três palimpsestos e é definido por:

Considerar as singularidades do palimpsesto do território em escalas de espaço e de tempo, a fim de diminuir as desigualdades sociais $e$ manter a identidade das Américas, expressas em três momentos distintos: (1) o palimpsesto dos povos originários, mais claramente presente na Mesoamérica; (2) o palimpsesto resultante da mistura entre colonizados $\mathrm{e}$ colonizadores, que definiu a arquitetura de inúmeras cidades e paisagens que se originaram da exploração de minerais e produção agrícola; (3) o palimpsesto da contemporaneidade, que se expressa, essencialmente, nas grandes cidades, lugar de concentração populacional planetária e das grandes inovações tecnológicas, que vêm expondo, na paisagem, não uma relação com lugares preexistentes, mas em outra escala, com um sistema global (Carta del Paisaje de las Américas, 2018, p. 7).

Definir um Princípio com olhar voltado às cidades é uma das especificidades da Carta da Paisagem das Américas, que as compreende como fenômenos ancestrais definidores de paisagens. Para López Austin e Milliones (2012), o período Clássico do esplendor mesoamericano ${ }^{13}$ foi marcado pela concentração de populações hierarquicamente organizadas em cidades e marca o período em que nasceu o urbanismo nas Américas, diferenciando-se a cidade do campo, ou seja, os lugares das atividades comerciais, artesanais políticas e religiosas, dos lugares das atividades voltadas à subsistência pela produção de alimento. Nesse "nascimento", as cidades como palimpsesto evoluíram definindo três tempos de

Paisagens-postais para sua conservação", da autora deste artigo, iniciada em 2019).

${ }^{13} \mathrm{Na}$ cronologia da Mesoamérica o período clássico se situa entre 200 e 900 d. C. (López Austin e Milliones 2012, p. 24).

Veras, L. M. S. C. paisagens: (1) dos povos originários - toltecas, teothiuacanos, astecas, maias e incas, entre outros -, (2) dos colonizadores mesclados aos povos originários das terras já conquistadas e (3) do atual povo "americano" e suas distintas paisagens do Norte, do Centro e do Sul das Américas.

O primeiro palimpsesto aponta, do ponto de vista geográfico, as influências da natureza que, provavelmente, contribuíram para definir uma ocupação mais nômade ao norte e ao sul - de climas frios e quentes -, contrastando com a temperada Mesoamérica, do sul do México à Costa Rica, até os Andes, na costa do pacífico na América do Sul, onde os vestígios de paisagem são fortemente assinalados pela arquitetura dos teotihuacanos, astecas, maias e os incas, como Teotihuacán (México), Tikal (Guatemala), Copán (Honduras), Tiahuanaco (Bolívia) ou Machu Picchu (Peru). E o contraste se dá por haver uma paisagem de cidade denominada "pré-hispânica" e não haver uma paisagem expressiva de cidade "pré-portuguesa" (no Brasil), por exemplo, constituída por vestígios índios de grandes estruturas urbanas de ocupação e apropriação do território, seja por povos semissedentários em florestas tropicais, como os Tupinambás, seja por povos nômades, caçadores, pescadores ou coletores, como os Botocudos. Diferentemente dos espanhóis na América Central e região dos Andes, que se confrontaram com os grandes impérios do México e do Peru, os portugueses "não encontraram sociedades nativas sedentárias no Brasil" (Williamson, 2016, p. 48-49), o que se revela nas estruturas de assentamento e organização espacial, diferentemente estruturadas. Por outro lado, os espanhóis se depararam com Tenochtitlán, na ilha do lago Texcoco, "uma espécie de Veneza da América, uma cidade de canais e passagens sobre a água, com cerca de 200.000 habitantes, mais populosa do que qualquer metrópole europeia contemporânea" (Williamson, 2016, p. 53). Estas cidades originárias do mundo ameríndio são testemunhos incontestáveis desta primeira estrutura do palimpsesto americano. Por conseguinte, aqui se estabeleceram as complexas relações entre índios e espanhóis, que "foram o caldeirão das sociedades híbridas que emergiram no continente" (Williamson, 2016, p. 49), fomentando a produção de paisagens que caracterizam o que se chamou de segundo palimpsesto americano.

Sobre o primeiro palimpsesto, os colonizadores redefinem a estrutura do segundo palimpsesto, caracterizado pela mescla entre colonizadores e colonizados, definindo tecidos urbanos de grande riqueza, ainda que, neste processo, a negação do primeiro palimpsesto 
signifique grande destruição e sofrimento para os povos originários, submetidos à dura imposição de novos sobre os valores secularmente consolidados. $^{14}$ Mais uma vez a riqueza da natureza como recurso, principalmente do ouro e da prata, ou do que se pode ser produzido e extraído pela agricultura, atrai os colonizadores e desta mistura caracterizam-se paisagens de cidades excepcionais, muitas delas hoje consideradas "patrimônio da humanidade" pela UNESCO, como as mexicanas Guanajuato, San Miguel Allende, Puebla, Querétaro, Oaxaca, como as brasileiras Olinda, Ouro Preto e Salvador, ou a colombiana Cartagena das Índias. Outras, como os pequenos povoados, tutelados pela Declaração de Tlaxcala, México (UNESCO-ICOMOS, 1982), são testemunhos culturais de uma forma de vida que associa comunidades locais, ambiente e arquitetura, dando identidade vernacular a um patrimônio não renovável que também define esse período no espaço e no tempo.

$\mathrm{O}$ terceiro palimpsesto caracteriza a paisagem dos dias atuais, aquela desencadeada essencialmente pelo processo de industrialização numa mescla que revela, predominantemente, semelhanças entre o centro e o sul das "Américas Ibéricas" e diferenças dessa América Ibérica ou Latina, com o norte, o da "América Anglosaxônica", principalmente do ponto de vista econômico e sociocultural. Este é o palimpsesto da contemporaneidade, predominantemente urbanizado, sendo as cidades hoje o lugar que concentra a maioria da população mundial, fenômeno também presente nas Américas que abrigam quatro entre as vinte cidades mais populosas do planeta (São Paulo, Cidade do

\footnotetext{
${ }^{14}$ A chegada dos espanhóis ao México e a forma como se estabeleceram na colônia foram marcadas por grande violência e exploração, gerando "un cúmulo de rencores y una desigualdad económica y social que hasta la fecha no ha desaparecido" (Muriá, 1982, p. 34). Baudot e Todorov, no livro Relatos astecas da conquista, exploram pela literatura dos povos vencidos, as consequências da resistência a esse confronto. Em nauatle, os astecas revelam "a incompreensível guerra que homens vindos de outro mundo travaram contra eles" (2019, p. 62). Por outro lado, como ressalta Williamson (2016), o descontentamento pela exploração também se manifestava entre os índios, gerando distintos impactos. No entanto, nada se compara ao massacre dos colonizadores sobre os colonizados, anunciando a chegada dos tempos modernos. Assim, a opressão dos dois lados, de diferentes formas e intensidades, aponta para a importância de se analisar este período por vários pontos de vista que vão se rebater, necessariamente, na paisagem.
}

Veras, L. M. S. C.
México, Nova Iorque e Lima). ${ }^{15}$ Por conseguinte, também é aqui que estão os maiores problemas sociais. Deste último palimpsesto, olha-se para trás e para frente, para o que se há que conservar e gerir e para o que se há que planificar, desenhar e melhorar das paisagens do futuro, visando diminuir as desigualdades sociais e os impactos sobre a natureza. Olha-se assim para as paisagens consideradas "notáveis" e as do "cotidiano", respaldadas pela Convenção Europeia da Paisagem (2000), iniciando-se pelo compromisso com o presente. Este palimpsesto é o ponto de mirada que nos impõe, como americanos, olhar para o passado, para entender o presente e pensar o futuro, compreendendo o papel primordial das cidades que "permanecem sendo o grande imã demográfico de nossos tempos, porque facilitam o trabalho e são a sementeira de nosso desenvolvimento cultural" (Rogers, 2013, p. 15).

\section{Princípio quarto: retomar a ética ambiental em sua relação com a estética}

O quarto Princípio espelhado no quarto Estrato, pauta-se na ética ambiental em sua relação com a estética e é definido por:

\begin{abstract}
Retomar a ética compreendida em sua relação com a estética, como condição intimamente associada à ética ambiental quando se propõe a resgatar o vínculo ancestral entre o homem e a natureza, num entendimento para além dos parâmetros antropocêntricos, quando a paisagem ganha, além de suas qualidades estéticas com a objetividade e subjetividade da beleza, o entendimento do mundo natural como valor moral (Carta del Paisaje de las Américas, 2018, p. 7-8).
\end{abstract}

O Relatório Brundtland da ONU denominado Nosso Futuro Comum, introduziu, em 1987, o conceito de "desenvolvimento sustentável" como eixo estruturador de uma política econômica global, visando atender as necessidades do presente sem comprometer as futuras gerações, com foco voltado para os mais pobres. O desenvolvimento sustentável é o maior dos desafios do século XXI que impõe uma mudança de paradigma, contrapondo-se à ideia de que a natureza é inesgotável e de que o desenvolvimento é ilimitado. Como condição vital

\footnotetext{
15 Para Carlos Leite (2012), o século 19 foi marcado pelos impérios, o 20 pelas nações e o 21 pelas cidades. Tickell (2013) aponta que em 1950, 29\% da população mundial habitavam em cidades, em 1990, 50\% e que, em 2025 , há a previsão de que $60 \%$ da população do planeta possam estar vivendo em cidades.
} 
para a vida no planeta, "não haverá paisagens se não houver natureza: a natureza será sempre a matriz das paisagens" (Serrão, 2013, p. 176).

O quarto Estrato, sobre a ética, trata do compromisso com a sustentabilidade e entendimento da indissociabilidade entre $\mathrm{o}$ homem e a natureza, expressos na paisagem. A ética ambiental impõe a compreensão da interdependência do todo vivo que para a América se dá no intercâmbio da rica diversidade de seus recursos naturais. Essa totalidade exige uma abrangência ainda mais larga, que extrapola fronteiras político-administrativas, como a ideia do que seja o bioma da Amazônia, que, ainda que se concentre no Brasil, se dilui entre nove países americanos. Ademais dessa localização, sua importância ecológica e ambiental repercute no planeta, exigindo que a responsabilidade e o compromisso com a conservação sejam partilhados entre todos os continentes num entendimento de que este é um legado global. O enquadramento estético do qual surge a paisagem na modernidade vincula-se intrinsecamente à subjetividade do sentir individual e soberano, distante dos fundamentos de aproximação à natureza, anteriores à modernidade. A ética ambiental se propõe a resgatar esta relação ancestral perdida entre o homem e a natureza, estreitando os laços sociais entre os homens, mas os compreendendo como integrantes de um sistema de seres vivos, numa relação para além dos parâmetros antropocêntricos, quando a paisagem associa às qualidades estéticas, a compreensão de que o mundo natural também é dotado de valor moral.

\section{Princípio quinto: (re)descobrir as raízes da americanidade como identidade}

O quinto Princípio espelhado no quinto Estrato pauta-se na americanidade como identidade e é definido por:

(Re) Descobrir as raizes da americanidade como condição para o futuro é o princípio que superpõe todos os outros na redescoberta das raízes que nos alicerçam como americanos e nos possibilitam continuar a projetar a paisagem do futuro consolidando nossa identidade. A condição de futuro está associada ao respeito à natureza, à cultura, aos valores estabelecidos, às singularidades da diversidade e ao direito à paisagem como um bem comum e patrimônio coletivo, que também incorpora, o direito à felicidade para todos (Carta del Paisaje de las Américas, 2018, p. 8).
Para o quinto Estrato convergem todos os outros, quando a americanidade passa a ser entendida como identidade das Américas. Os seus fundamentos se apoiam na recomposição dos valores descortinados pelos outros estratos natureza, cosmovisão, cultura e ética - que recompostos, articulam a redefinição de uma nova compreensão do que seja 'ser americano' bem como aquilo que compõe a paisagem das Américas num sentido de (re)descobrimento.

Ainda que este Princípio e Estrato reforcem a junção de recomposição dos outros estratos para se consolidar a existência de uma "identidade americana", pairam discussões que poderão se desdobrar em inquietações para o futuro. Afinal, mesmo que se busque consolidar a conquista de uma "identidade americana", o ponto de partida é questionado por alguns pela própria denominação dada às terras do Novo Mundo, descoberto em 1492 pelos espanhóis e mais tarde denominado de América, numa homenagem a Américo Vespúcio, registrada em mapa de 1507 elaborado por Martin Waldseemüller, que oficializa o continente descoberto. ${ }^{16}$ Segundo Edmund O'Gorman (1976), a dúvida se estabelece a partir do fato de os conquistadores não terem consciência sobre o lugar aonde haviam chegado, imaginando terem alcançado as Índias e não as terras de um continente ancestralmente já conquistado por avançadas civilizações. ${ }^{17} \mathrm{O}$ que os desbravadores encontraram foi uma paisagem produto da mescla entre respeito às condições impostas pela natureza e um determinado tipo de organização social em comunidade; respeito à natureza entre perplexidade e temor tomados num sentido sagrado e avançadas técnicas de

${ }^{16}$ Embora o desbravador genovês Cristóvão Colombo tivesse chegado a terras do novo mundo entre 1492 e $1498 \mathrm{e}$, portanto, anterior às expedições de Américo Vespúcio, entre 1497 e 1504, vem de Vespúcio o nome dado ao novo continente, "América", extraído de referência assinalada em mapa elaborado por Martin Waldseemüller e reconhecido como documento gerador da cartografia moderna no século XVI (Lester, 2012).

${ }^{17}$ Os espanhóis que chegam ao México, por exemplo, encontraram três grandes reinos: Tetzcoco, Tlacopan e México-Tenochtitlan, organizados em tríplice aliança (Escalante Gonzalbo et al., 2014). Ao se depararem com o México-Tenochtitlan, no lago Texcoco, é notória a expressão de assombro e espanto do soldado espanhol Bernal Díaz del Castillo: "nos quedamos admirados, y decíamos que parecía a las cosas de encantamiento [...] no sé como lo cuente: ver cosas nunca oídas, ni aún soñadas, como veíamos [...]" (Díaz Del Castillo, 1955 [1568] apud Bernal García e García Zambrano, 2006, p. 37-38). 
construção, agricultura e planejamento econômico e social, numa intrincada rede de relações simbólicas, mitológicas e rituais (Wolf, 1963), ainda que a exploração de impostos fosse um dos pontos de discórdia entre os povos originários.

Somado a essa dúvida, Quijano e Wallerstein (1992, p. 591) reconhecem a América como "producto histórico de la dominación colonial europea", fruto da expansão do moderno sistema capitalista mundial que, para se estabelecer, necessitou se expandir geograficamente, assim como implantar métodos de exploração do trabalho e criar fortes aparatos de Estado próprios da economia capitalista. Nesse processo, a América foi essencial para estas duas primeiras necessidades, com seus espaços fartos e abundante riqueza natural, assim como farta população submetida ao trabalho escravo e em grande parte dizimada pelas condições opressivas a que foram submetidas, situação que, intrinsecamente, vincula-se ao conceito de "americanidade". Como aparato ideológico de uma forma de ver e transformar o mundo, este conceito provoca inquietação quando se busca têlo como instrumento de unificação da paisagem das Américas, acentuado pelas grandes desigualdades econômicas, sociais e culturais principalmente entre as duas Américas, Anglosaxônica e Latina, que seguem desafiando o entendimento da América como um só continente.

Este é um dos grandes desafios da Carta da Paisagem das Américas. Se Enrique Dussel (1973) sinaliza a necessidade de resgate da estrutura de nossa consciência latino-americana para entendê-la como valor universal, estende-se agora este resgate para todo o continente, com o propósito de se (re)descobrir e reconstruir o conceito de "americanidade", respeitando-se na unidade a diversidade de nossa singularidade. Esse respeito inclui o direito coletivo ao desfrute de paisagens que traga bem estar social, diminua as desigualdades e possa falar de nossa "americanidade" como condição de futuro, alimentando os gestos voltados para a Conservação, o Planejamento, a Gestão e o Desenho de novas de paisagens.

\section{De Caminha aos caminhos futuros da Paisagem das Américas: considerações finais}

Ao descrever uma parte do novo mundo, a Carta do Achamento do Brasil escrita por Pero Vaz de Caminha há mais de cinco séculos abre uma das portas de compreensão das idiossincrasias do continente americano, que, para além de uma 'descoberta' pelos europeus, revela que este 'novo velho mundo' foi, na verdade, 'inventado' como América entre os séculos XV e XVI e hoje, no século XXI, reivindica em uma outra carta, a Carta da Paisagem das Américas, o reconhecimento e consolidação de séculos de sua história expressos na paisagem que lhe dá identidade. Não por acaso, ao lançar o desejo de se construir uma carta paras as Américas, Peñalosa lança a questão: “¿Cuáles serían estas peculiaridades de nuestro continente que nos permitan afirmar hoy, la identidad globalizada de un paisaje americano?"18 Como questão central, a resposta a esta aparentemente simples questão permeou o desafio do processo de construção aqui descrito, que se desdobra em outros futuros.

Brotando dos Estratos, Considerandos e Princípios, os Objetivos pontuam formalmente estes desafios futuros, quando se reconhece esta Carta como um "instrumento capaz de contribuir à conquista da felicidade como direito de todos" (Carta del Paisaje de las Américas, 2018, p. 8). O entendimento de "felicidade", extraído das cartas já produzidas e ampliado para o continente, implica a busca pelo bem estar social ancorado no respeito à natureza, à cosmovisão, à cultura, à ética ambiental em sua relação com a estética, que, reunidos, trazem o sentido de americanidade como identidade. Assim, formalmente explícitos nos 18 Objetivos imbricados entre si e interdependentes, os desafios podem ser reunidos em três grupos: (1) os técnicos, (2) os voltados à educação e (3) os políticos.

Os desafios técnicos envolvem, inicialmente, o propósito de que esta Carta auxilie a tomada de decisões voltadas à conservação, ao planejamento, à gestão e ao desenho de novas paisagens. Espera-se que o gesto de desenhar a paisagem, intrinsecamente atribuído ao Arquiteto da Paisagem e estendido aos profissionais que interferem oficialmente na paisagem, seja inserido em ações governamentais e considere as especificidades, idiossincrasias e desejos das populações locais, como valores americanos, próprios da "americanidade" como identidade que se busca incorporar. Entre os desafios está também o reconhecimento das cidades como paisagens especiais e que, como categoria do pensamento, devem ser incluídas em políticas públicas visando ao desenvolvimento urbano sustentável. A construção de um inventário e catálogo das paisagens das Américas fecha os desafios técnicos a serem enfrentados, quando, numa costura vertical, este será um instrumento de

\footnotetext{
18 Trecho da mensagem de boas-vindas do discurso de posse proferido por Raquel Peñalosa, presidenta da IFLA Região das Américas, em 15 ago. 2014.
} 
apoio ao planejamento, à preservação e à gestão das paisagens americanas. Neste caso, sua construção deve ser acordada entre países e pode ser construído entre as instituições afiliadas à IFLA Américas, o que, de partida, exigirá um grande esforço coletivo.

Os desafios voltados à educação partem da constatação de que, sem educação paisagística e patrimonial dos envolvidos - especialistas, técnicos e população -, não será possível consolidar uma cultura de respeito à paisagem como patrimônio coletivo. Para a educação formal, estimula-se a incrementação de cursos de graduação e pós-graduação e ao processo educativo insere-se o desafio de promover e incorporar a participação social como condição necessária às tomadas de decisões públicas, voltadas ao planejamento, à conservação, à gestão e ao desenho de novas paisagens.

Os desafios políticos podem ser considerados os mais complexos porque dependem da relação e acordos que devem ser estabelecidos entre países. Com o propósito de ser um instrumento de confluência de um pensamento americano de paisagem, o primeiro dos desafios é reconhecê-la como documento que estabelece um marco legal que poderá auxiliar a aproximação entre a América Anglo-saxônica e a América
Ibérica. Esta não é uma tarefa simples, constatando-se inclusive que os Estados Unidos ainda não construíram a sua Carta de Paisagem. Como este país, com todas as implicações econômicas, políticas e sociais que exerce no continente e, simultaneamente, se distanciam do próprio continente criando suas muralhas, vai responder às questões aqui colocadas? Por outro lado, como não incorporar a dimensão histórica e visão de sustentabilidade pioneira dos Estados Unidos, expressa na proteção dos primeiros parques nacionais do planeta? A Carta assume assim o desafio de se reconhecer como documento conceitual que considera a unidade de nossa diversidade e que esta compreensão possa orientar a construção de estratégias a serem adotadas por cada Estado membro na definição de seus instrumentos legislativos específicos. Portanto, deve ser incorporada às políticas públicas setoriais (numa escala local) e ser um instrumento que possa contribuir para a construção da Convenção Global da Paisagem (numa escala global), compromisso assumido em 2010, em Suzhou, na China.

Esse processo está sintetizado na Figura 4, que reúne as decisões que pautaram a construção da Carta da Paisagem das Américas.

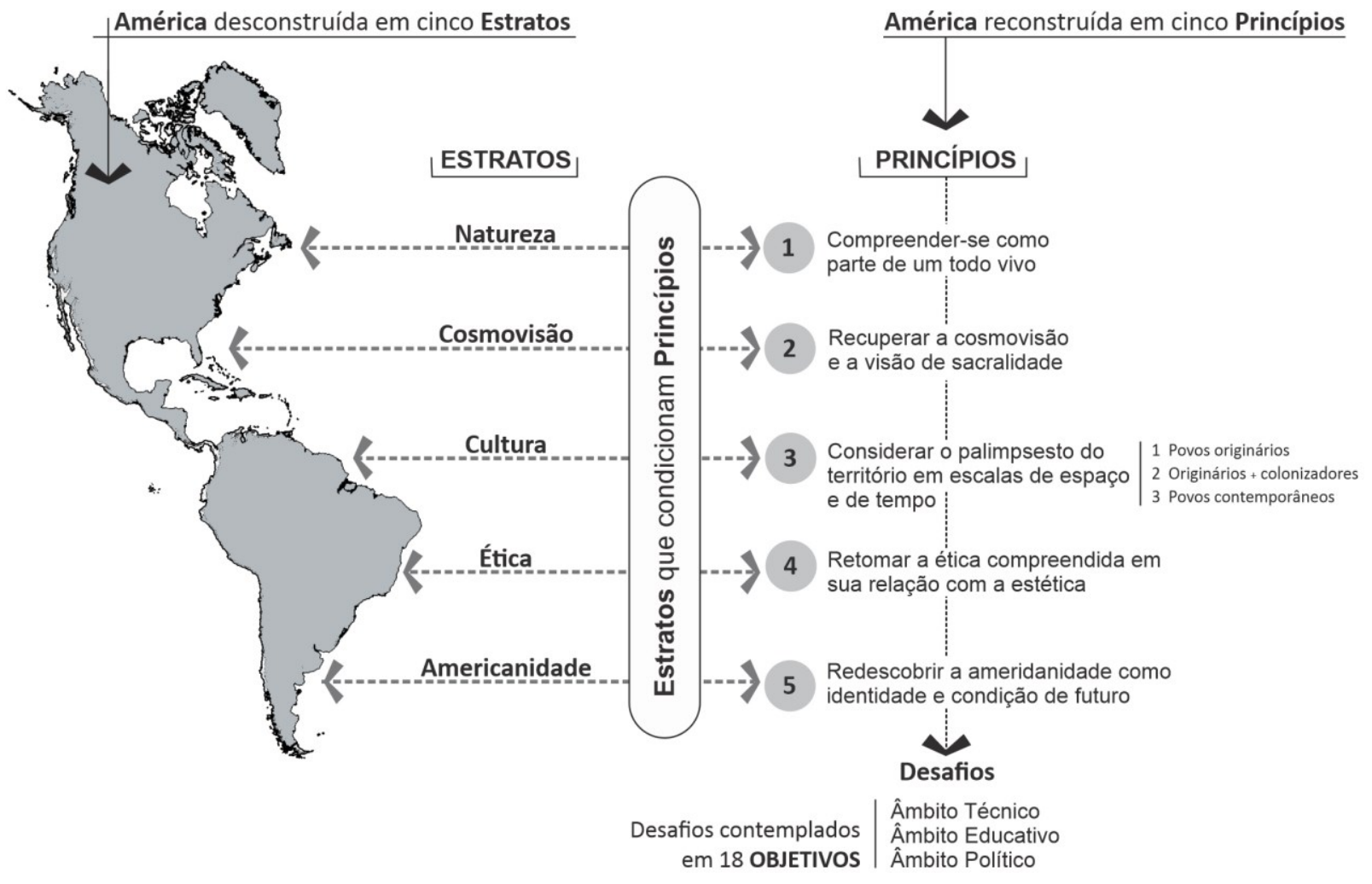

Figura 4 - Estrutura esquemática da Carta da Paisagem das Américas: os Princípios, espelhados nos Estratos, pontuam os desafios contemplados nos Objetivos. 
Além dos desafios formalmente expostos enquanto documento conceitual, outros vêm se desdobrando do próprio processo de divulgação e apropriação para a assinatura da Carta por seus signatários. O protocolo não é claro quanto aos procedimentos, e o Comitê Redator segue como Comitê Difusor, com seus cinco membros locados no Canadá, México, Costa Rica e Brasil, o que dificulta o estabelecimento de um procedimento mais sistemático dos trabalhos.

A Carta da Paisagem das Américas já foi apresentada na Cidade do México, ${ }^{19}$ na Argentina, ${ }^{20}$ no Chile $^{21}$, na Guatemala ${ }^{22}$ e a partir do Brasil, entre 2018 e 2020, foi apresentada em três fóruns internacionais ${ }^{23} \mathrm{e}$ em três fóruns locais de programas de pós-graduação de universidades públicas brasileiras. ${ }^{24}$ Nestes fóruns, algumas questões começam a despontar, direcionando possíveis discussões e ampliação de encaminhamentos futuros. Das questões já levantadas, duas se destacaram como provocadoras para continuar se discutindo o documento, esclarecendo-se dúvidas que antecedem a assinatura e comprometimento dos países: a participação social e o conceito de felicidade.

"Como esta Carta foi construída? Houve participação social?" A resposta a esta primeira questão expõe a ausência de uma participação social na construção desta Carta. Escrita por

19 Conferencia Regional IFLA Américas /UAM-A. Descubrir los paisajes de las Américas: diseñar, planificar, conservar y gestionar. Ciudad de México, 2018.

${ }^{20}$ ISCCL PAISAJES CULTURALES ICOMOS-IFLA, Mendoza, 2018.

21 Conferencia Regional IFLA AR-UCEN-ICHAP, Santiago de Chile, 2019.

${ }^{22}$ Conferencia Regional IFLA AR Guatemala, 2020.

$235^{\circ}$ CIAP Congresso Internacional de Arquitetura Paisagística: Paisagem e Arte, promovido pela Associação Brasileira de Arquitetos Paisagistas (ABAP, 2019); III Colóquio Internacional "Imaginário: Construir e Habitar a Terra" (III ICHT2019), promovido pela Universidade Federal de Pernambuco, FAUUSP, Université de Lyon e Université Grenoble Alpes e $1^{\circ}$ Seminário Internacional Paisagem e Jardim: Burle Marx em sintonia com o tempo, promovido pelo Laboratório da Paisagem da Universidade Federal de Pernambuco, 2020.

${ }^{24}$ Disciplinas da Pós-Graduação em Desenvolvimento Urbano da Universidade Federal de Pernambuco: "Conservação dos Espaços Públicos e da Paisagem" e "Gestão da Conservação Integrada" e do Mestrado Profissional em Projeto e Patrimônio do Programa de Pós-Graduação em Arquitetura da Universidade Federal do Rio de Janeiro: "Seminários em Projeto e Patrimônio: Novas Abordagens em Patrimônio".

Veras, L. M. S. C. arquitetos com formações e experiências distintas no trato com a paisagem, não foi discutida com outros profissionais que também a estudam, nem foi aberta à participação social como um todo. Tendo sido construída a partir das cartas de paisagem já produzidas nas Américas até 2018 método explicitado acima -, acredita-se que esta participação possa ter sido realizada por cada país na construção de suas cartas individuais, em algum momento, além de incorporar experiências de participação experimentadas pelo Comitê Redator. Esta checagem não foi realizada e a opção de sua construção a partir das 12 cartas já elaboradas, considerou, também, que as instituições responsáveis por cada país, tomaram a Convenção Europeia da Paisagem como lastro e referência, que de partida impõe a importância da participação social na proteção, gestão e ordenamento das paisagens. Essa ausência, no entanto, pode repercutir mais adiante com questionamentos que poderiam ter sido discutidos em um comitê de especialistas responsáveis, por exemplo, pelas cartas de paisagem já produzidas por seus respectivos países e incluir a participação de profissionais de várias disciplinas que têm a paisagem como objeto de reflexão, além de distintos grupos sociais. Ainda que neste momento não tenha sido efetivada a Carta abre esta possibilidade em seu oitavo Objetivo quando se afirma como um dos seus propósitos:

Ser um instrumento que possa orientar as propostas de intervenção nas paisagens não só de arquitetos da paisagem, mas de todos os demais profissionais, de diversas áreas do conhecimento, assim como as comunidades que trabalham a gestão e a conservação, que têm a paisagem como objeto e interesse de suas intervenções (Carta del Paisaje de las Américas, 2018, p. 9).

Só com a ampla participação social implantando uma cultura de colaboração própria de um processo de gestão se poderá validar as tomadas de decisão tanto para a proteção quanto para a transformação de paisagens. Cabe, então, como desdobramento para sua homologação, que seja discutida democraticamente em fóruns mais amplos, com foco nos seus cinco Princípios e que se ajuste o instrumento, quando detectada essa necessidade.

$\mathrm{Da}$ construção à aprovação pelos signatários e seus desdobramentos em instrumentos legais, caracteriza-se como processo que demanda tempo e maturação. Esse tempo pode ser encurtado se a paisagem em si for objeto de interesse que reúna e aproxime, em vez de distanciar distintos grupos de profissionais, num 
esforço conjunto para superar os desafios que lhes são inerentes e que exigem debates e amplos consensos. Para a América Latina, a LALI desencadeou em 2020 um processo coletivo de construção do que denominou de "Convenio Latinoamericano del Paisaje", que segue em 2021 em processo de difusão virtual e estruturação.

Outras discussões que incluem a paisagem estão sendo conduzidas pela UNESCO, que, em 2022, comemora o $50^{\circ}$ aniversário da Convenção do Patrimônio Mundial e o $30^{\circ}$ aniversário da introdução da Paisagem Cultural como categoria de proteção, e para essa ocasião, deu início a um amplo processo global de rediscussão dos conceitos que definem determinadas paisagens como bens patrimoniais de valor excepcional universal. Reconhecendo a importância dessa discussão que revela a ampliação dos interesses sobre a paisagem quanto mais se discuti-la, melhor -, talvez a Carta da Paisagem das Américas aponte alternativas de reflexão, porque se insere em outro percurso, não se limitando a considerar, apenas, as paisagens excepcionais, que correspondem ao que a UNESCO define como "Paisagem Cultural". Esta categoria, que se refere à "obra combinada da natureza e do homem", introduzida no Encontro Técnico do Comitê do Patrimônio Mundial em La Petite, França, em 1992 (Veras, 2014), estaria mais atrelada à noção de bem cultural, distanciando-se da concepção "da geografia tradicional na qual a paisagem cultural é toda e qualquer paisagem alterada pelo homem" (Ribeiro, 2007, p. 52). Por isso mesmo, a Carta da Paisagem das Américas não se define como Carta da Paisagem Cultural das Américas, porque considera como objeto de seu interesse tanto as paisagens notáveis (de valor excepcional universal), quanto as paisagens da vida cotidiana, sejam elas ordinárias, reveladoras da cultura local ou mesmo degradadas. Nessa perspectiva incorpora da Convenção Europeia da Paisagem "um olhar mais largo por não adotar a paisagem cultural como foco, mas a paisagem, como produto cultural em sentido lato" (Veras, 2014, p. 133).

Este percurso adotado para a Carta da Paisagem das Américas entende assim, numa visão sistêmica, que todas as paisagens estão interrelacionadas de algum modo e, de algum modo em diferentes escalas, são apropriadas e importantes para alguém, devendo ser cuidadas, inseridas num processo de planejamento e gestão e se necessário, desenhadas ou redesenhadas para serem reincorporadas ao conjunto com qualidade. É essa visão sistêmica que diz respeito aos princípios sustentáveis do respeito ético à natureza nos lugares e a natureza dos lugares, numa imbricada e entrelaçada relação de 'naturezas' e 'culturas', que poderá assegurar, inclusive, a conservação daquelas paisagens consideradas excepcionais. A visão sistêmica nos permite compreender que a paisagem degradada hoje poderá ser uma paisagem notável amanhã. Afinal, produto da cultura, que paisagem não seria cultural?

"O que se entende por felicidade como patrimônio coletivo das Américas?" Esta segunda questão toca o primeiro objetivo da Carta, que se propõe a "ser um instrumento capaz de contribuir para a conquista da felicidade como direito pleno de todos os americanos" (Carta del Paisaje de las Américas, 2018, p. 8). Na análise de conteúdo das 12 cartas produzidas, a palavra "felicidade" é recorrente em quatro delas: Carta Chilena del Paisaje, Carta Colombiana del Paisaje, Carta Costarricense del Paisaje e Carta del Paisaje de Centro América y el Caribe, e esta última, reunindo outros países da região central das Américas. ${ }^{25}$ No conjunto, as cartas apontam a diversidade de suas paisagens como valor a ser reconhecido juridicamente, bem como reconhecem o direito ao seu desfrute como fundamental para o bem estar social e a qualidade de vida da população, por ser um direito de todo cidadão. A felicidade também aparece associada à conservação dos ecossistemas como condição necessária à vida coletiva e é posta a importância da Arquitetura da Paisagem nesse processo. O conceito sobre o que seja "felicidade como patrimônio coletivo" não é objeto de discussão da Carta da Paisagem das Américas, que assume em sua estrutura a importância explícita legitimada por quatro outras cartas, uma delas congregando outros países. Outras questões poderiam surgir: qual a relação entre felicidade e bem estar social? Felicidade traz bem estar social? Bem estar social traz felicidade? O que se entende por felicidade para as Américas? A felicidade pode estar associada à paisagem como patrimônio coletivo?

São muitas questões que exigem um profundo mergulho teórico-conceitual que deve considerar, essencialmente, a história, a cultura, a natureza nos e dos lugares e os respectivos valores às paisagens, atribuídos pelos americanos. É provável que outras questões surgissem de um amplo processo participativo. Ainda assim, a resposta não seria fácil e caberia retomar reflexões pioneiras como as colocadas por Epicuro em sua

25 A Asociación de Arquitectos Paisajistas de Centro América y el Caribe fundada em 2008, em 2010 já contava com seis países membro (Cedeño, 2010). 
Carta sobre a felicidade, ${ }^{26}$ escrita que se inicia com a afirmação da importância do exercício da filosofia, como condição para se encontrar a felicidade. Eduardo Giannetti, em diálogos filosóficos entre 'processo civilizatório' e 'felicidade', afirma que

Discutir a felicidade significa refletir sobre o que é importante na vida. Significa ponderar os méritos relativos de diferentes caminhos e pôr em relevo a extensão do hiato que nos separa, individual e coletivamente, da melhor vida ao nosso alcance (Giannetti, 2002, p. 183).

Talvez a chave esteja na diminuição do hiato entre $\mathrm{o}$ individual $\mathrm{e} o$ coletivo $\mathrm{e}$ nas possibilidades que se multiplicam pelos inúmeros interlocutores. Talvez a chave também esteja na reconexão com a natureza, que Ailton Krenak chama de cosmos e reivindica esforços para uma aproximação respeitosa entre a humanidade e a terra, como um só organismo, capaz de proporcionar o experimento do "prazer de se estar vivo, de dançar, de cantar" (2019, p. 26), de diferentes formas e em diferentes lugares, que distintas culturas socialmente constroem como paisagem.

Os desafios já detectados são muitos e inúmeros outros se desdobrarão para a implementação desta Carta a ser acordada por seus signatários. Este processo está apenas começando e se inicia pelo reconhecimento jurídico-institucional das paisagens, para que sejam inseridas em políticas públicas de desenvolvimento das Américas. A partir desse reconhecimento, os desafios se inscrevem no pacto entre países para a Conservação, o Planejamento, a Gestão e o Desenho de novas paisagens numa articulação que respeite as idiossincrasias, os valores, as necessidades e distintos desejos de futuro para a América como continente. Se a carta de Caminha abriu uma fresta curiosa sobre o Novo Mundo, a Carta da Paisagem das Américas poderá franquear a emancipação de um olhar plural sobre $o$ continente americano que tende a revelar, simultaneamente, a existência de um sentido de unicidade.

\footnotetext{
${ }^{26}$ A Carta sobre a felicidade, como ficou conhecida a Carta a Meneceu, discípulo de Epicuro (341-270 a.C), descreve a busca pela felicidade relacionada ao corpo e ao espírito, acreditando que preservar a vontade e a liberdade são preceitos fundamentais ao bem estar, o que inclui considerar, também, a sociedade e a consciência moral (Epicuro, 2002).
}

Veras, L. M. S. C.

\section{Agradecimentos}

Agradeço ao Dr. Saúl Alcántara Onofre pelo convite para integrar a equipe de trabalho que construiu a Carta da Paisagem das Américas, durante meu pós-doutoramento no México, na Universidad Autónoma Metropolitana, unidad Azcapotzalco, entre 2017 e 2018, como bolsista da Capes (Processo No PE 99999.000071/201700 ), a quem igualmente agradeço. Não poderia ter participado da escrita dessa Carta se não estivesse no México, mergulhada num processo de profunda imersão nas coisas desse lugar, que me fizeram perceber com mais intensidade, longe do meu país, o quanto a paisagem se define a partir da relação intrínseca entre coisas e pessoas, natureza e cultura, história e costumes, ali também expressos no jeito de viver, comer e até de trançar os cabelos, provavelmente herdado dos ancestrais mexicanos. Cada lugar com suas idiossincrasias, para mim se revelou como um corpo grudado à alma, como se partes da América assim se insinuassem na forma de um texto-paisagem.

\section{Referências}

Baudot, G.; Todorov, T., 2019. Relatos astecas da conquista. São Paulo: Editora Unesp.

Bardin, L., 1977. Análise de conteúdo. Lisboa: Edições 70.

Bartalini, V., 2007. Petrarca é o culpado. Arquiteturismo, São Paulo, ano 01, n. 010.04, Vitruvius, dez. Disponível em: $<$ https://vitruvius.com.br/revistas/read/arquitet urismo/01.010/1386>. Acesso: 25 nov 2020.

Bernal García, M. E.; García Zambrano, A. J., 2006. El altepetl colonial y sus antecedentes prehispánicos: contexto teórico-historiográfico. In: Fernández Christlieb, F.; García Zambrano, A. J. (coord.). Territorialidad y paisaje en el altepetl del siglo XVI. México: FCE, Instituto de Geografia, UNAM, p. 31-113.

Bernd, Z., 2002. Americanidade/Americanização. In: XVII Encontro Nacional da Associação Nacional de Pós-Graduação e Pesquisa em Letras E Linguística (ANPOLL), Gramado. Anais [...]. Gramado: FAURGS-UFRGS, p. 1$24 . \quad$ Disponível em: $<$ https://partnership.files.wordpress.com/2008/ 02/americanidade-e-americanizacao.pdf $>$ Acesso: 25 jan. 2020.

Besse, J-M., 2006. Ver a terra: seis ensaios sobre a paisagem e a geografia. São Paulo: Perspectiva.

Borrini-Feyerabend, G.; Dudley, N.; Jaeger, T.; Lassen, B.; Broome, N. P.; Phillips, A.; Sandwith T., 2017. Governança de Áreas 
Protegidas: da compreensão à ação. Série Diretrizes para melhores Práticas para Áreas Protegidas, No. 20, Gland, Suiça: UICN.

Busquets Fàbregas, J.; Cortina Ramos, A., 2009. Las cartas del paisaje. In: Busquets Fàbregas, J.; Cortina Ramos, A. (coord.). Gestión del paisaje: manual de protección, gestión y ordenación del paisaje. Barcelona: Editorial Ariel, S. A., p. 425-446.

Carta da Paisagem das Américas. Federação Internacional de Arquitetos Paisagistas Região Américas (IFLA-AR), Universidad Autónoma Metropolitana unidad Azcapotzalco (UAM-A). Cidade do México, 28 set. 2018. Disponível em: <http://paisagem.net.br/2019/07/10/cartada-paisagem-das-americas-agora-emportugues/>. Acesso: 4 jun. 2020.

Carta del Paisaje de las Américas. International Federation of Landscape Architects Americas Region (IFLA-AR), Universidad Autónoma Metropolitana unidad Azcapotzalco (UAM-A). Ciudad de México, 28 set. 2018. Disponível em:

$<$ https://www.ufpe.br/documents/39726/0/08.C arta+de+las+Americas_final_12.pdf/1c7926b7 -4667-4bee-ae7b-fce008af9f9 $\mathrm{b}>$. Acesso: 7 nov. 2018.

Cauquelin, A., 2007. A invenção da paisagem. São Paulo: Martins Fontes.

Cedeño, Y., 2010. Nueva organización membro en Centro América y el Caribe. IFLA Newsletter Issue, n. 86, 10-11. Disponível em: $<$ https://www.yumpu.com/es/document/read/1 4226725/no-86-un-nuevo-ano-un-nuevomundo-bienvenidos-ca->. Acesso: 2 fev. 2020.

Convenção Europeia da Paisagem. Decreto n. 4/2005. Florença, 20 out. 2000.

Dussel, E., 1973. América Latina: dependencia y liberación. Buenos Aires: Fernando García Cambeiro,

D'Angelo, P., 2011. Os limites das actuais teorias da paisagem e a paisagem como identidade estética dos lugares. In: Serrão, A. V. (coord.). Filosofia da paisagem. Uma antologia. Lisboa: Centro de Filosofia da Universidade de Lisboa, p. 419-439.

Epicuro., 2002. Carta sobre a felicidade: (a Meneceu). São Paulo: UNESP.

Escalante Gonzalbo, P.; García Martínez, B.; Jáuregui, L.; Zoraida Vásquez, J.; Speckman Guerra, E.; Garciadiego, J.; Aboites Aguilar, L., 2014. Nueva historia mínima de México. México, D. F.: El Colegio de México.

Giannetti, E., 2002. Felicidade: diálogos sobre o bem-estar na civilização. São Paulo: Companhia das Letras.
Giucci, G., 2003. Uma carta: império e nação. In: Rocha, J. C. de C. (org.). Nenhum Brasil existe. Pequena enciclopédia. Rio de Janeiro: UniverCidade Editora, p. 49-62.

Gonçalves, V., 2012. Entrelaçar corpo e paisagem: Petrarca, Rousseau e Nietzsche. In: Serrão, A. V. (coord.). Filosofia e arquitectura da paisagem. Um manual. Lisboa: Centro de Filosofia da Universidade de Lisboa, p. 105115.

Gumbrecht, H. U., 2003. Quem foi Vaz de Caminha? In: Rocha, J. C. de C. (org.). Nenhum Brasil existe. Pequena enciclopédia. Rio de Janeiro: UniverCidade Editora, p. 3547.

Holloway, M., 2003. Prece nas areias: Paula Rego e as representações visuais da Primeira Missa no Brasil. In: ROCHA, João Cezar de Castro (org.). Nenhum Brasil existe. Pequena enciclopédia. Rio de Janeiro: UniverCidade Editora, p. 63-71.

Krenak, A., 2019. Ideias para adiar o fim do mundo. São Paulo: Companhia das Letras.

Lampreia, D., 2012. Por uma política de paisagem: a propósito da Convenção Europeia da Paisagem. In: Serrão, A. V. (coord.). Filosofia e arquitectura da paisagem. Um manual. Lisboa: Centro de Filosofia da Universidade de Lisboa, p. 253-265.

Leite, C., 2012. Cidades sustentáveis, cidades inteligentes: desenvolvimento sustentável num planeta urbano. Porto Alegre: Bookman.

Lester, T., 2012. A quarta parte do mundo: a corrida aos confins da terra e a épica história do mapa que deu nome à América. Rio de Janeiro: Objetiva.

López Austin, A.; Millones, L., 2012. Dioses del norte, dioses del sul: religiones y cosmovisión en Mesoamérica y los Andes. México: Ediciones Era.

Muriá, J. M., 1982. Conquista y colonización en México. México: Fondo de Cultura Económica.

Nogué Font, J.; Sala Martí, P., 2009. Los catálogos de paisaje. In: Busquets Fàbregas, J.; Cortina Ramos, A. (coord.). Gestión del paisaje: manual de protección, gestión y ordenación del paisaje. Barcelona: Editorial Ariel, S. A., p. 397-426.

O'Gorman, E., 1984. La invención de América. México: Fundo de Cultura Económica.

Peñalosa, R.; Alcántara, S.; Jankilevich, C.; Veras, L.; Ocejo Cázares, M. T. (redactores)., 2018. Descubrir los paisajes de las Américas. Diseñar, planificar, conservar y gestionar. Carta del paisaje de las Américas. Astragalos: Revista Cuatrimestral Iberoamericana, México, 
n.25, p. 125-133, diciembre. Disponível em: $<$ https://outarquias.wordpress.com/2019/05/28/ nuevo-numero-de-la-revista-astragalo-25diciembre-2018/>. Acesso: 3 fev. 2020.

Querol, M., 2010. A. Manual de gestión del patrimonio cultural. Madrid: Ediciones Akal, S. A.

Ribeiro, R. W., 2007. Paisagem cultural e patrimônio. Rio de Janeiro: IPHAN/ COPEDOC.

Rogers, R., 2013. Cidades para um pequeno planeta. São Paulo: Editora Gustavo G. Gilli, Ltda.

Santos, E. da S., 2016. O ensaio como forma nas obras de Miguel de Unamuno e de José Enrique Rodó. In: II Simpósio Internacional Pensar e Repensar a América Latina. São Paulo. Anais [...]. São Paulo: PROLAM-USP. p. 1-14. Disponível em: $<$ https://sites.usp.br/prolam/ii-simposiointernacional-pensar-e-repensar-americalatina_anais/>. Acesso: 26 jan. 2020.

Schenk, L. B. M., 2008. Arquitetura da paisagem: entre o Pintoresco, Olmsted e o Moderno. Tese (Doutorado em Arquitetura e Urbanismo, Áreas de Concentração em Teoria e História da Arquitetura e do Urbanismo) - Escola de Engenharia de São Carlos da Universidade de São Paulo, São Carlos.

Serrão, A. V., 2012. Paisagem, uma categoria em transição. In: Serrão, A.V. (coord.). Filosofia e arquitectura da paisagem. Um manual. Lisboa: Centro de Filosofia da Universidade de Lisboa, p. 317-332.

Silva, J. M. da; Sá Carneiro, A.R.; Feitosa Júnior, W. de B.; Rolim, M. E. D. de O., 2019. A Praça de Casa Forte: um jardim histórico, um patrimônio cultural do Brasil. Anais do Museu Paulista: História e Cultura Material [internet], v. $27, \quad 1-30$. DOI: http://dx.doi.org/10.1590/198202672019v27e05

Simmel, G., 2011. Filosofia da paisagem [1913]. In: Serrão, A. V. (coord.). Filosofia da paisagem. Uma antologia. Lisboa: Centro de Filosofia da Universidade de Lisboa, p. 42-51.

Tickel, C., 2013. Introdução. In: Rogers, R. Cidades para um pequeno planeta. São Paulo: Editora Gustavo G. Gilli, Ltda, p. ii-vii.

Unamuno, M., 2002. Americanidad. Caracas: Biblioteca Ayacucho.

Veras, L. M. de S. C. Paisagem-postal: a imagem e a palavra na compreensão de um Recife urbano. Tese. (Doutorado em Desenvolvimento Urbano), Universidade Federal de Pernambuco, Recife, 2014. Disponível
$<$ https://repositorio.ufpe.br/bitstream/1234567 89/13174/1/TESE\%20L\%c3\%bacia\%20Maria $\% 20 \mathrm{de} \% 20$ Siqueira\%20Veras.pdf $>$. Acesso: 15 mar. 2021.

Williamson, E., 2016. História da América Latina. Lisboa: Edições 70.

Wolf, E., 1967. Pueblos y culturas de Mesoamérica. México: Ediciones Era S. A.

Zoido Naranjo, F., 2009. El Convenio Europeo del Paisaje. In: Busquets Fàbregas, J.; Cortina Ramos, A. (coord.). Gestión del paisaje. Manual de protección, gestión y ordenación del paisaje. Barcelona: Editorial Ariel, S. A., p. 299-315. 